\title{
Integrated 3D facies modeling of the Mangahewa Formation, Maui Gas Field, Taranaki Basin, New Zealand
}

\author{
A. K. M. Eahsanul Haque ${ }^{1} \cdot$ Md. Aminul Islam ${ }^{1} \cdot$ Mohamed Ragab Shalaby $^{1} \cdot$ Junaid Sadeque $^{2}$
}

Received: 9 October 2017 / Accepted: 3 April 2018 / Published online: 13 April 2018

(c) The Author(s) 2018

\begin{abstract}
3D seismic data, well logs, core-based lithofacies and photographs have been combined to interpret and model the depositional facies of the Mangahewa Formation of the Maui Gas Field, Taranaki Basin, New Zealand. The primary objective of the study is to generate a robust facies model for the Middle to Late Eocene (47-37 Ma) Mangahewa Formation of the field. The facies model has included eighteen depositional facies spatially distributed over the gas field. These facies are further subgrouped into three broad depositional facies associations, namely marginal marine, shallow marine and offshore environment. We have identified that marginal marine is the most dominant facies association (64\%) within the model. The model visualizes estuarine and shoreface sand geobodies dominating over other facies within the model. Both geobodies comprise over $40 \%$ of all the facies interpreted in the field. The entire modeling process involves a novel stochastic approach using unique workflow that follows 3D gridding, coding of the facies classes and multiple iterations over the interpreted facies. The model therefore realistically visualizes potential facies responsible for "good"-quality reservoir sands in the Mangahewa Formation with possible retrogradation from older to younger succession.
\end{abstract}

Keywords Maui Gas Field · Facies modeling · Sequential indicator simulation (SIS) · Variogram analysis · Depositional environment

\section{Introduction}

Maui Gas Field is the largest hydrocarbon-producing field of New Zealand to date, with a field size of $150 \mathrm{sq}$. km. It is considered to be a two-way dip closure anticlinal structure (Fig. 1). This field is situated in the southern region of the Taranaki Basin and is bounded from both east and west by two regional faults, Cape Egmont Fault and Whitiki Fault (Stagpoole and Nicol 2008; Laird 1993). This gas field has been producing from three main reservoir sands, namely the Mangahewa, Kaimiro and Farewell formations of the Kapuni Group (King and Thrasher 1996; Bryant et al. 1994; Voggenreiter 1993). The reservoir sands are broadly NE-SW trending with a succession of cyclic deposition of terrestrial, marginal marine to shallow marine facies (King

$\triangle$ A. K. M. Eahsanul Haque

akmeahsan@yahoo.com

1 Department of Physical and Geological Sciences, Faculty of Science, Universiti Brunei Darussalam, Jalan Tungku Link, Gadong BE1410, Brunei Darussalam

2 AECOM, 100 Park Avenue, New York, NY 10017, USA and Thrasher 1996). This fairway includes Middle to Late Eocene Mangahewa Formation, which is the main focus of this study. There have been very few studies regarding facies modeling on this producing field, thus creating a gap in understanding the facies distribution of the subsurface reservoirs. Although stochastic modeling is a relatively new technology (Barboza et al. 2009; Mayall et al. 2006), it is highly suitable to interpret heterogeneity and uncertainty of the facies in the subsurface. To fulfill the gap, we have developed an understandable and robust three-dimensional facies model of the Mangahewa reservoir. This is essential in deciphering depositional variability within the studied formation with implications for both exploration and development.

\section{Regional geological settings}

Taranaki Basin is the largest basin of New Zealand which is overprinted by Neogene convergent margin-related tectonics (Stagpoole and Nicol 2008; King and Thrasher 1992; King 1990). The entire New Zealand subcontinent is characterized by a passive margin and subsidence followed by consecutive 
Fig. 1 Maui Gas Field and surroundings, Taranaki Basin, New Zealand. Modified after King and Thrasher (1996), Higgs et al. (2012) and Haque et al. (2016)

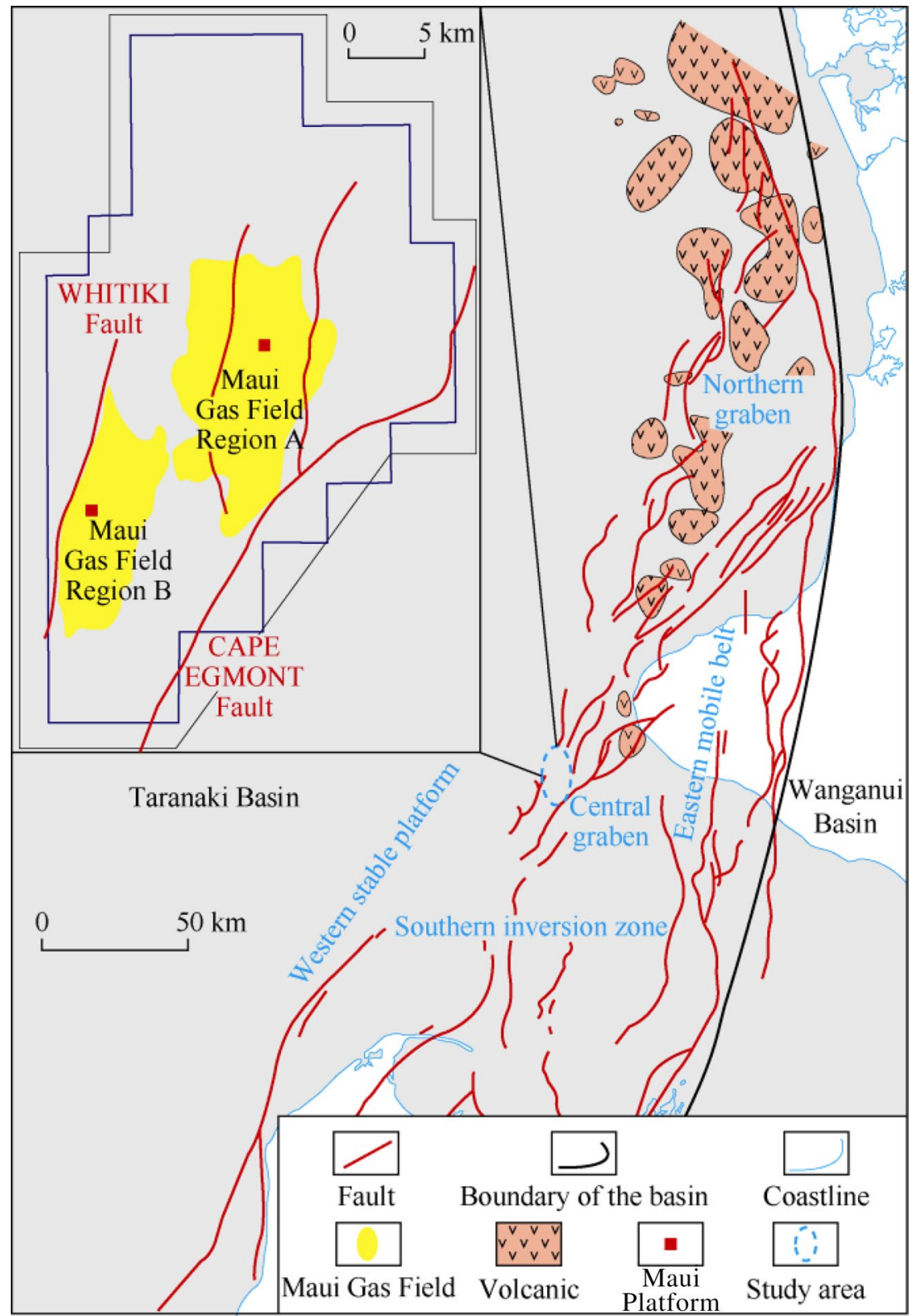

accumulation of Paleocene-Eocene sediments across the shelfal and coastal plains of the basin (King 1990). It is to be noted that sedimentation mostly occurred within the passive margin. There had been sea level rise and fall cycles during Paleogene period (King 1990; King and Thrasher 1996). Most of the basin remained tectonically quiescent till the end of the Eocene. However, it is also observed that an overall pattern of asymmetric eastward thickening of Middle to Late Eocene strata suggests regional fault-controlled subsidence during this period (Stagpoole and Nicol 2008). Major formations within the field have low regional dip angle $\left(\sim 10^{\circ}\right)$ in the north and $\left(\sim 15^{\circ}\right)$ in the southern part of the field (Haque et al. 2016).
The Kapuni Group and the Moa Group are two timeequivalent subdivisions of the Paleocene-Eocene strata (Fig. 2). The Kapuni Group is further subdivided into the Paleocene Farewell Formation, Early to Middle Eocene Kaimiro Formation and Middle to Late Eocene Mangahewa Formation and uppermost McKee Formation (King and Thrasher 1996). Our focus of study is the Mangahewa Formation which overlies the Kaimiro Formation and underlies the Turi Formation of the same group. The Mangahewa is the thickest formation among the formations of the Kapuni Group and hence the most prolific reservoir interval within the Maui Gas Field. The base of this formation is interpreted to be a conformable contact (Higgs et al. 2012). 
Fig. 2 General stratigraphic succession of Taranaki Basin, New Zealand. Modified after King and Thrasher $(1992,1996)$

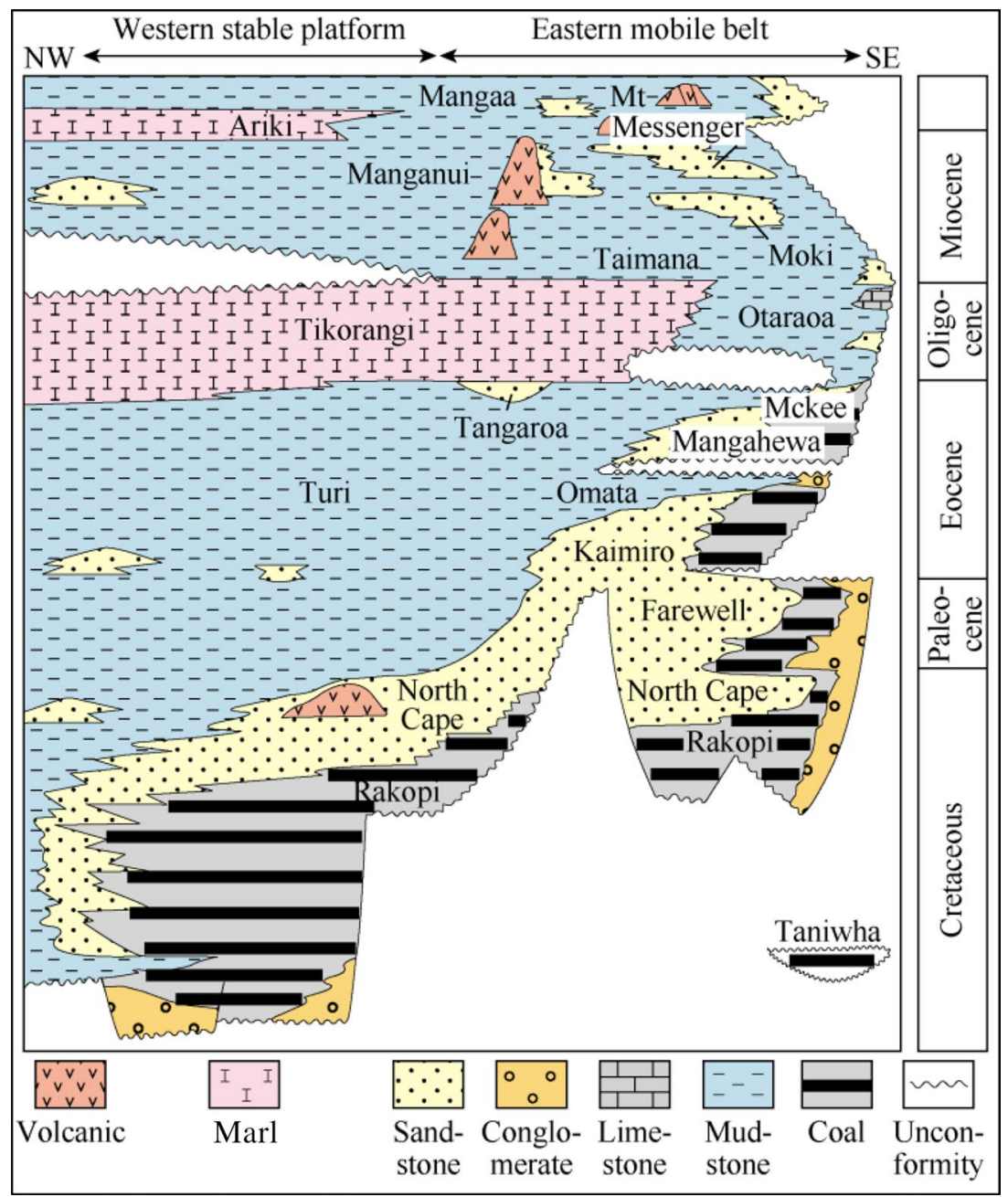

\section{Methodology}

\section{Maui dataset}

The data made available for the study were comprised of $1500 \mathrm{~km}^{2}$ of 3D seismic data, 17 wells including well logs (GR, resistivity, density, neutron, sonic), formation tops and completion reports, core photographs and related lithofacies of Maui-5, Maui-6 and Maui-7. Using the geodetic reference plane (New Zealand Geodetic Datum-1949) and Universal Transverse Mercator (UTM) as the projection system, 3D seismic data along with the interpreted Mangahewa horizon were georeferenced. 3D seismic data (in time domain) of the Maui Gas Field were stacked (post-stack) and migrated. The 3D seismic survey (in SEG-Y format) used in the study was processed using 100-1340 Inlines and 01-4000 Xlines, 1836 samples/traces, sampling interval of $3 \mathrm{~ms}$ and total time of $5500 \mathrm{~ms}$. Wireline logs used in this study are all original logs with no corrections applied. Core depths were slightly shifted downward to match with the wireline $\operatorname{logs}$ available for this study. The original stratigraphic formation tops were slightly adjusted to the log responses across the field.

\section{Workflow}

Facies modeling using stochastic algorithm was applied in this field considering the structural framework proposed earlier in the same field (Haque et al. 2016). We followed well-seismic tie approach for this study. We used checkshots to convert the density log and sonic-derived velocity from depth to time domain for the studied wells. After the calculation of reflectivity series, convolution of a wavelet was performed with the reflectivity series to generate synthetic traces within the well location which was later used for matching the real seismic and synthetic to pick up the horizons/geological boundaries from the known geology given at the well location. The marked horizons/geological boundaries were used for well correlation in depth domain and also 
used for seismic interpretation in time domain to find the lateral facies continuity. In case of potential mismatches with the traces, we "stretched and squeezed" synthetic traces for best fitting with that of the seismic.

The well-tie approach was performed generating synthetic seismogram in studied wells. After the process, the seismic reflector was matched with trace signal in seismic to synthetic trace in the wells (Fig. 3).

The lithofacies and the facies associations were inferred from the core observations and interpretations of the Maui-5,
Maui-6 and Maui-7. The depositional facies interpretations were mainly being performed considering $\log$ responses of the studied wells. We interpreted lithofacies as well as depositional facies that may have occurred in the studied wells. We also got few previously published reports on electrofacies and depo-facies of the Mangahewa Formation, which we used as a guide for this study. After the depo-facies were properly (geologically) interpreted, we matched the cored interval with the un-cored intervals using the log response of the cored interval as a calibration for the uncored intervals.

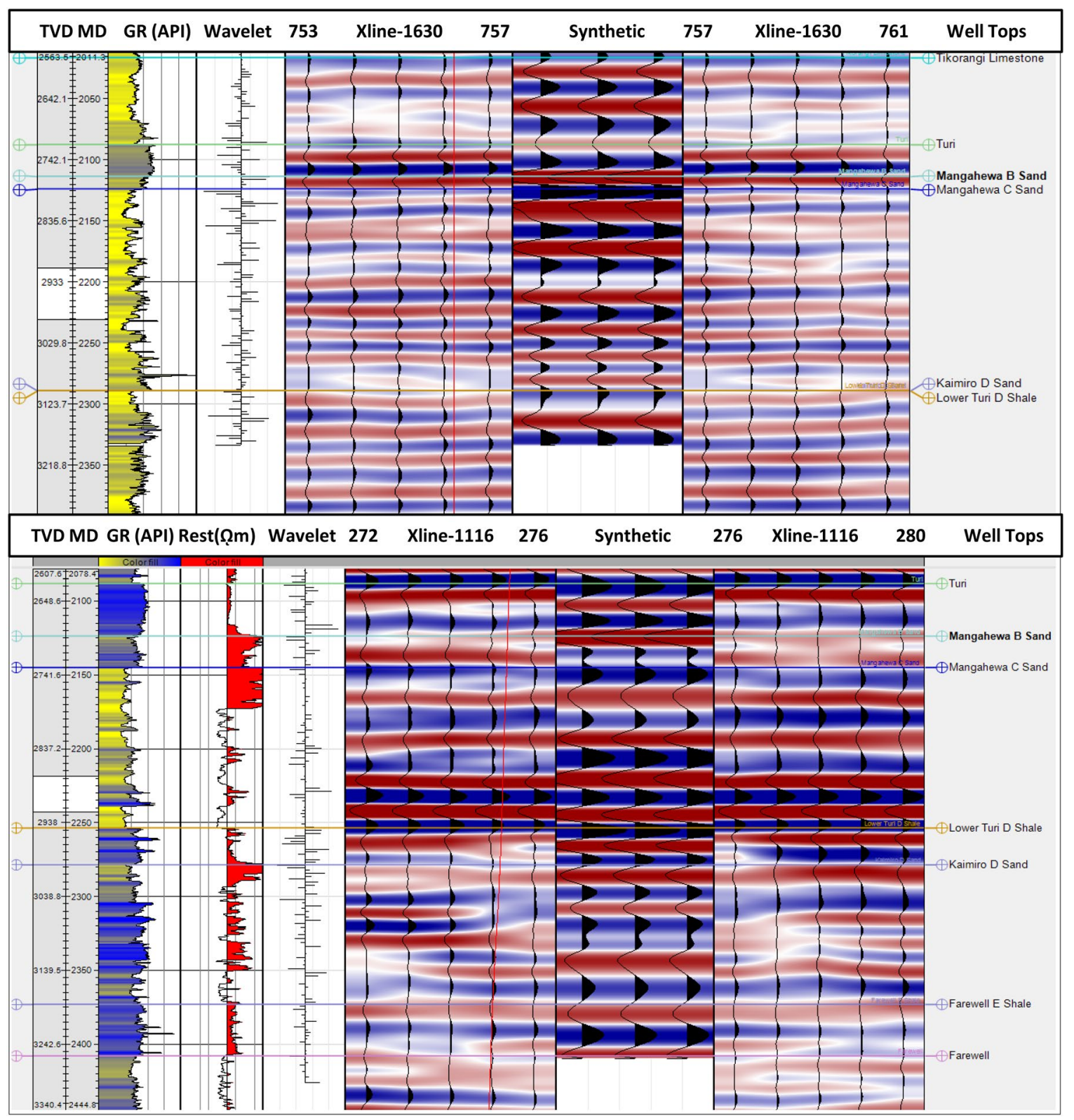

Fig. 3 Synthetic seismogram for the Maui-1 (top) and Maui-2 (bottom) wells. Synthetic seismograms were generated for horizon matching with the 3D seismic cube of the Maui Gas Field. The trace matching was performed on both time and depth seismic for better horizon interpretation. It is observed that the trace matching between the synthetic-well log-real seismic is fairly accurate (Maui-3/Maui-4/Maui-5/ Maui-7 was also used to perform well-synthetic tying 
This led us to proceed for the 3D facies model of the formation of interest. Facies classification (Dorfman et al. 1990) was built at a well-to-well level which was then populated within the 3D grid nodes of the Mangahewa reservoir. Similar studies were performed on several different sedimentary basins by Rodríguez-Tovar et al. (2017), Alalade (2016), Harishidayat and Johansen (2015), Li et al. (2014) and Reading and Collinson (1996). Interpretations were later combined into the modeled grid which leads to the following workflow (Fig. 4).

\section{Algorithmic approach}

Choosing the right algorithm is the key for distributing geological parameters in space and time. Facies proportions are generally considered to be most critical (Kupfersberger and Deutsch 1999; Kupfersberger et al. 1998; Deutsch 1998). The process itself involves modeling of facies grids with correct geometries and dimensions within the field. Facies discretization has been applied by Pyrcz et al. (2012), Harding et al. (2004) and Strebelle and Zhang (2004) on different hydrocarbon fields; therefore, the approach is taken to capture detailed facies

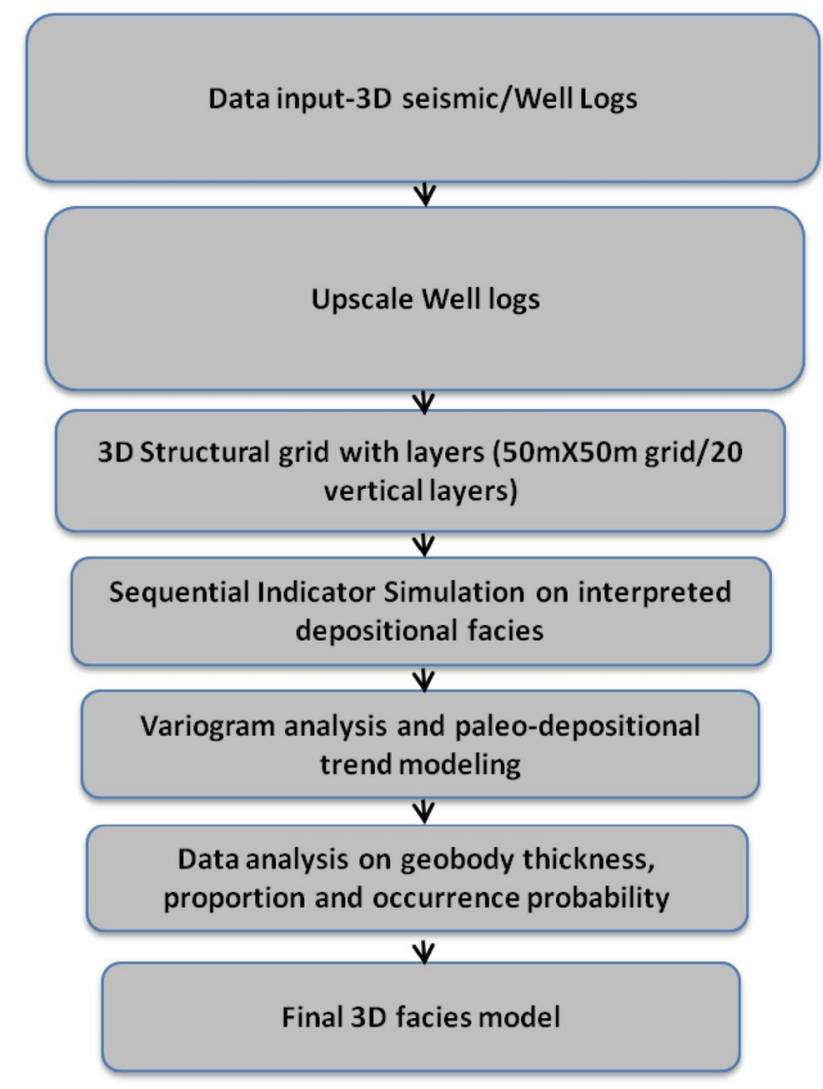

Fig. 4 Standardized workflow for 3D facies modeling of the Mangahewa Formation associations within Mangahewa reservoir as well. It generally follows tolerable computing response with each assigned grid "nodes." To obtain the best possible results, 40 realizations for 20 layers of Mangahewa Formation (20X2) using sequential indicator simulation (SIS) was performed.

Pixel-based SIS algorithm is used with facies coding (Kupfersberger and Deutsch 1999) for the model that can be traced back to Geostatistical Software Library (GSLIB) (Xu and Journel 1993). However, common challenges in geomodeling, such as producing realistic modeled scenarios, logical facies boundary conditions as well as their proportions, were considered while modeling for this study. We applied collocated co-kriging in SIS to obtain spatial distribution of depositional facies, i.e., paleodepositional trend of all the layers within Mangahewa Formation. Moreover, the reason for choosing SIS over TGS is the simplicity and usability of the algorithm. For this study we developed somewhat unique approach in which we used SIS along with object-based facies coding. So this entire method follows a relatively new technique for geobody detection and quantification. During the first stage of this study, we developed a part of the 3D model using TGS algorithm, but numerous modeling iterations were taken without considerable success on facies probability and trending spatially. That is why, SIS with facies coding approach was considered for this study. The model considers nearest-simulated node values and variogram data for effective spatial and vertical facies distribution within the Mangahewa reservoir.

\section{Facies interpretation}

The Upper Eocene Mangahewa reservoir was interpreted as a mixture of marginal to shallow marine environment having a NE-SW trending shoreline (Higgs et al. 2012; King et al. 1995; Palmer and Bulte 1991). For this study, we have interpreted lithofacies through cored and uncored sections of the available wells following Jadoon et al. (2017), Zhong et al. (2017), Wang et al. (2014), Hammer et al. (2010), Cohen et al. (1996) and Seybold et al. (1996). Twelve lithofacies were interpreted based on sedimentological characteristics and bioturbation markers (Table 1). Eighteen depositional facies and 3 facies associations were identified and interpreted (Table 2). Core litho-logs of Maui-5 and Maui- 6 are thoroughly described in Figs. 5 and 6. In general, these include 6 sandstone-dominated lithofacies, 4 siltstone-dominated lithofacies and 2 mudstone-dominated lithofacies. It is to be noted that lithofacies analysis was one of the major indicators for depositional facies interpretation (Walker et al. 2016; Miall 2016; Turner and Bryant 1995; Seybold

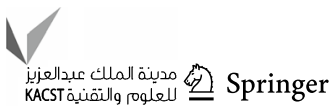




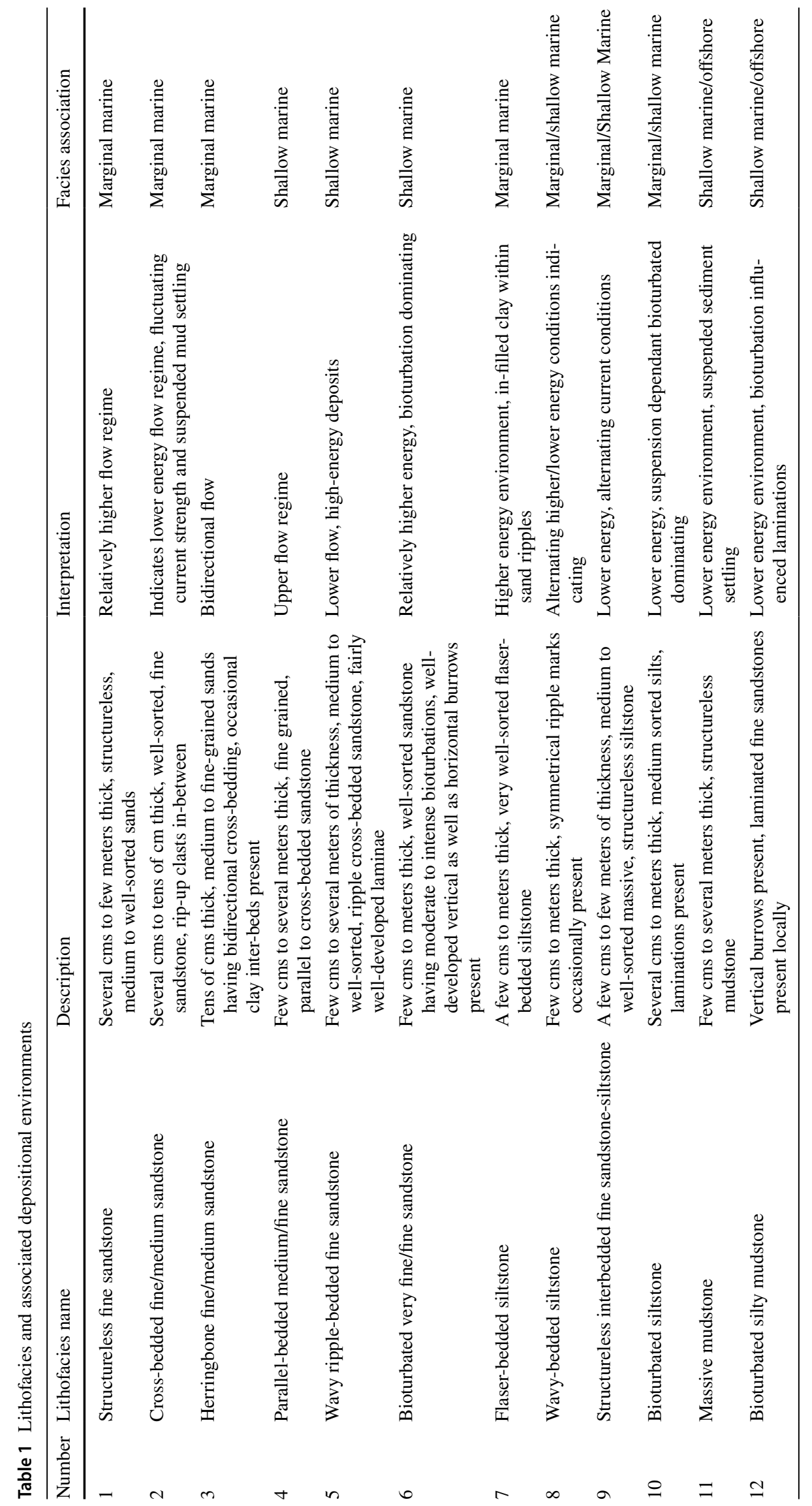




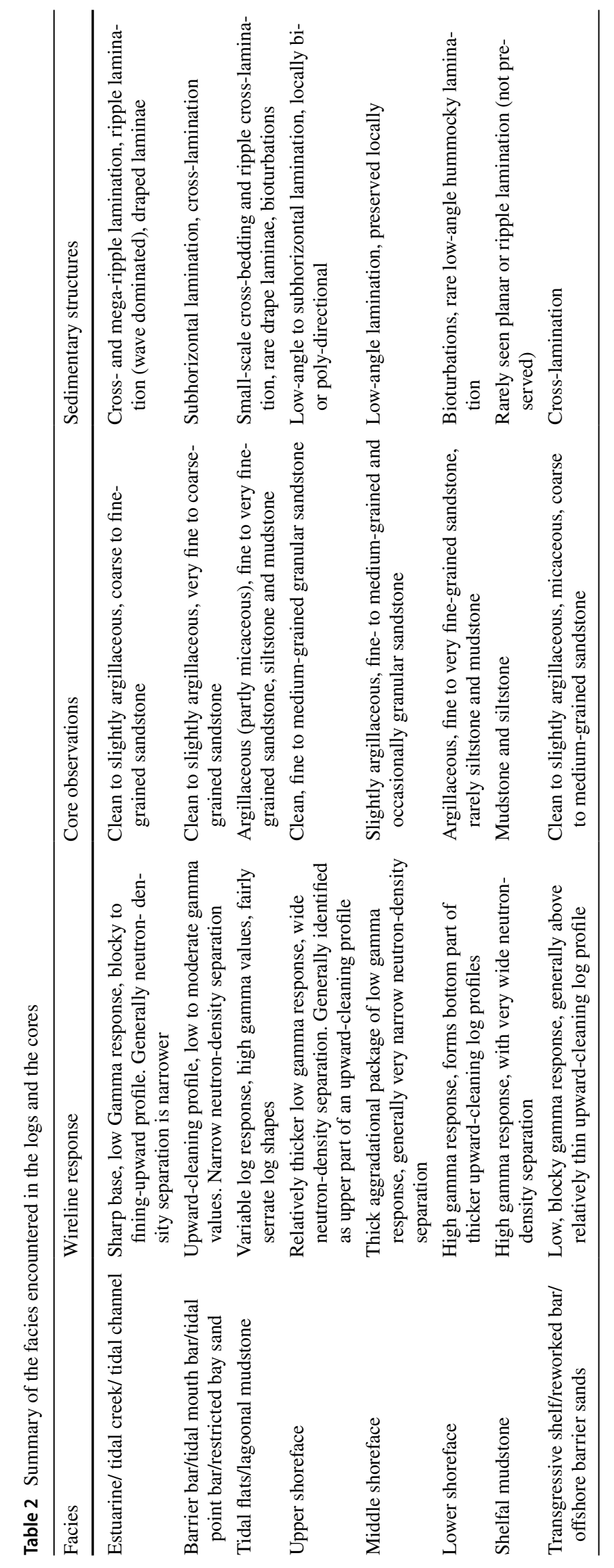


Fig. 5 Maui-5 litholog interpreted is from the cores. Bioturbations are absent from $2848 \mathrm{~m}$ to the bottom of the interpreted section. Graded to parallel beddings indicate relatively higher flow regime within the interval. From 2838 to $2847 \mathrm{~m}$ minor bioturbations are present with parallel to flaser beddings, intercalations of mudstone and sandstone with higher flow regime at the bottom of the interval. Massive sandstones covering 2826-2836 m exhibit moderate to intense bioturbations within this interval

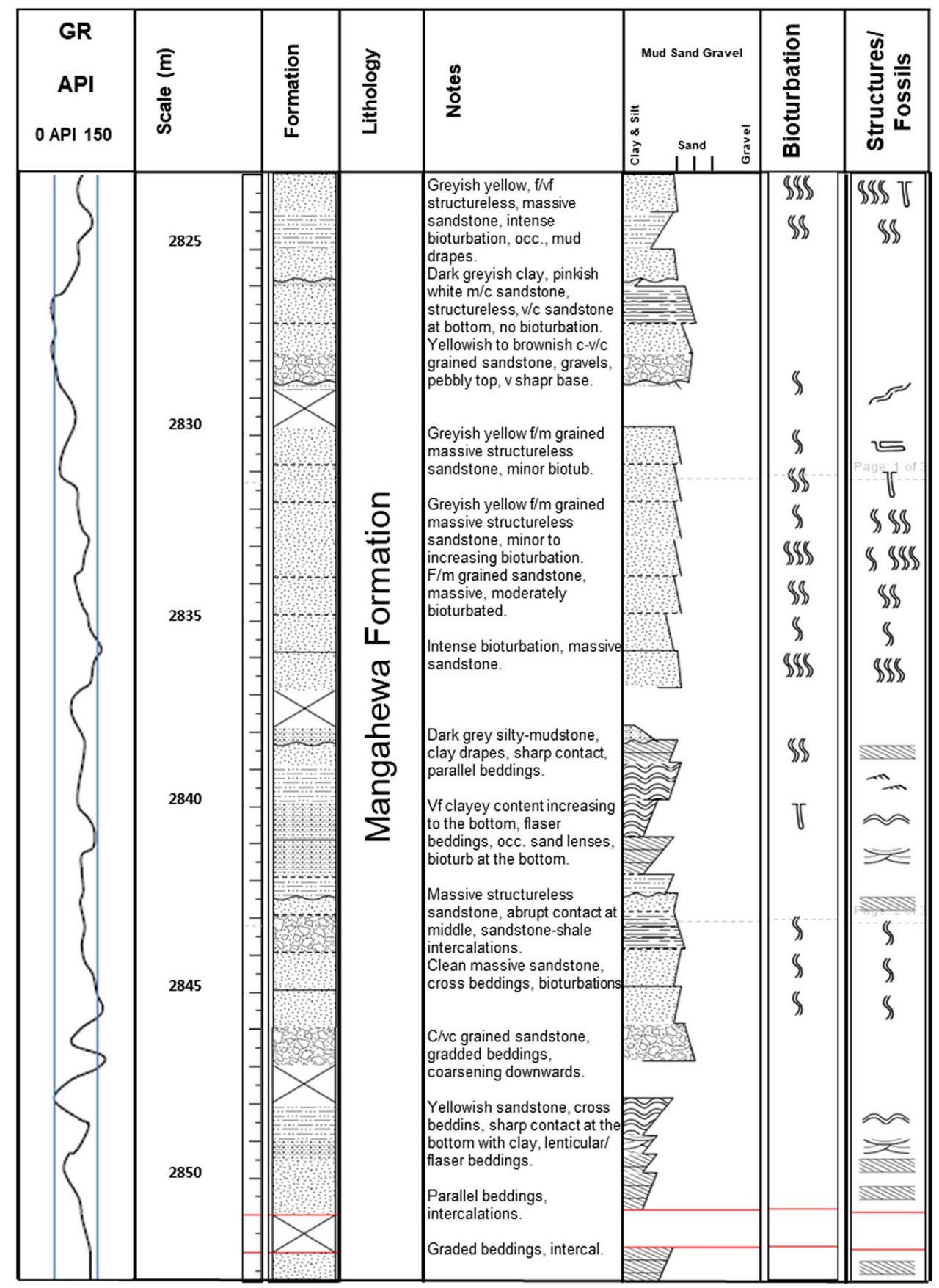

et al. 1996). Cored sections are interpreted based on the well log response, depositional facies variability and historical reports. Based on the results of the interpretation, we used the outputs of the depositional facies into the geobody model for simulating uncored sections along the studied wells (Figs. 7, 8, 9). The calibration for the facies was performed to match subsurface geology of the studied formation. Maui-5, Maui-6 and Maui-7. 


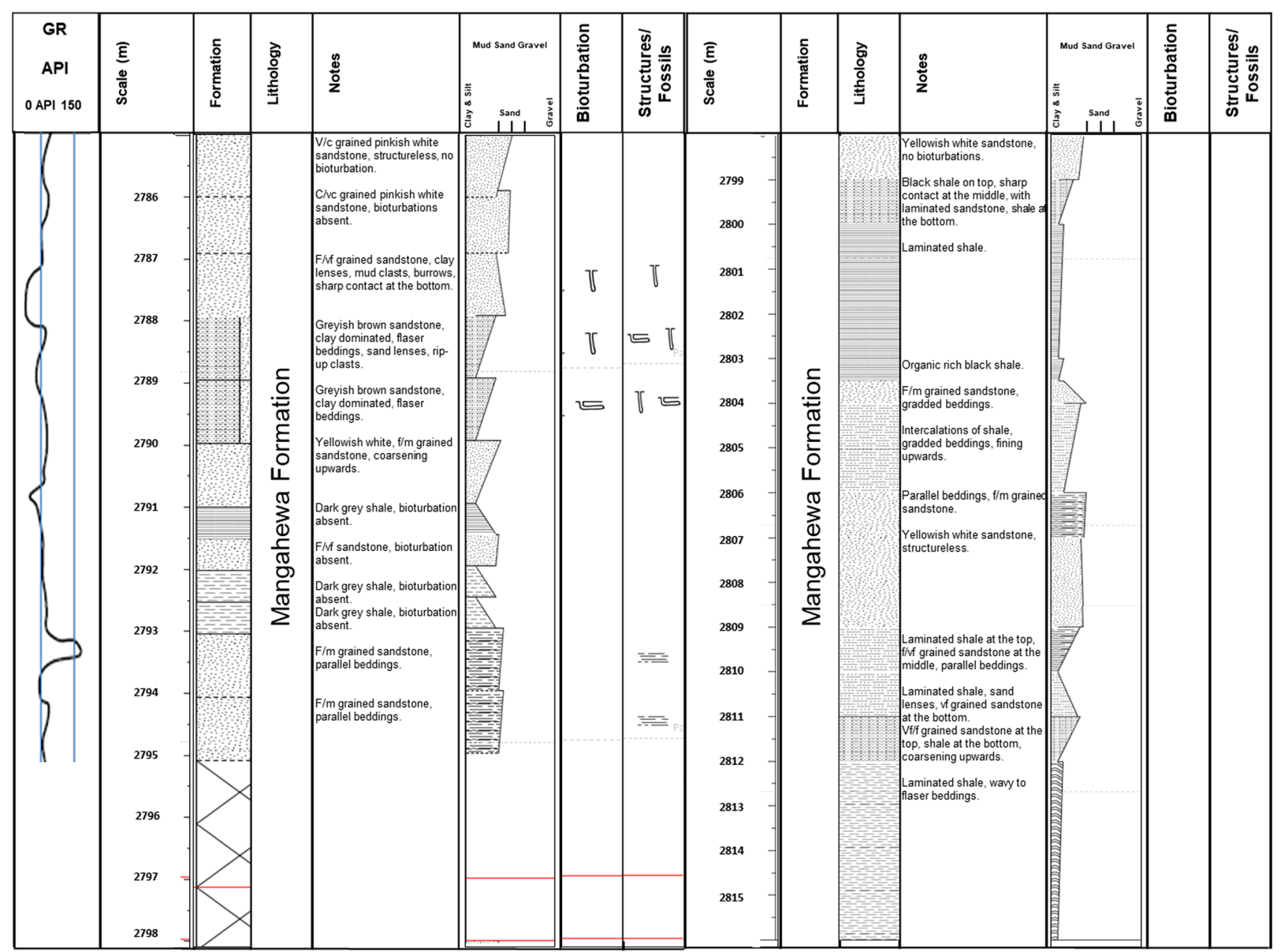

Fig. 6 Maui-6 litholog is interpreted from the cores. Bioturbations are absent from 2798 to $2816 \mathrm{~m}$. Thick shale beds along with massive to parallel-bedded sandstone encountered within the interval. Minor bioturbations are present from 2785 to $2795 \mathrm{~m}$. The interpreted interval is characterized by higher energy (no bioturbation) sandstone at the top, intercalations of bioturbated sandstone and clay with flaser bedding, rip-up clasts in the middle and shale beds at the bottom

\section{Marginal marine facies association}

The marginal marine environment encompasses a wide range of facies that reflect the interaction of fluvial and marine processes. However, for this study we only have identified dominance of marine characteristics within the marginal marine association. The range of interpreted depo-facies includes tidal channel sandstones, estuarine or distributary channels, tidal flat, mud flat, lagoonal deposits and flood-tidal delta deposits. The marginal marine environment is probably the most complex of all environments
(Howell et al. 2008; Yoshida et al. 2004; Reading and Collinson 1996; Dalrymple and Rhodes 1995), with common vertical and lateral changes in lithology that has negative impact on reservoir connectivity. The facies are explained in the following sections:

\section{Tidal mouth bar/delta-inlet sand}

The thickness of the tidal mouth bars interpreted from the well $\log$ s reaches up to $20 \mathrm{~m}$. From the core study, tidal mouth bar facies consist of cross-bedded, mediumto fine-grained sandstone and flaser-bedded sandstone. 


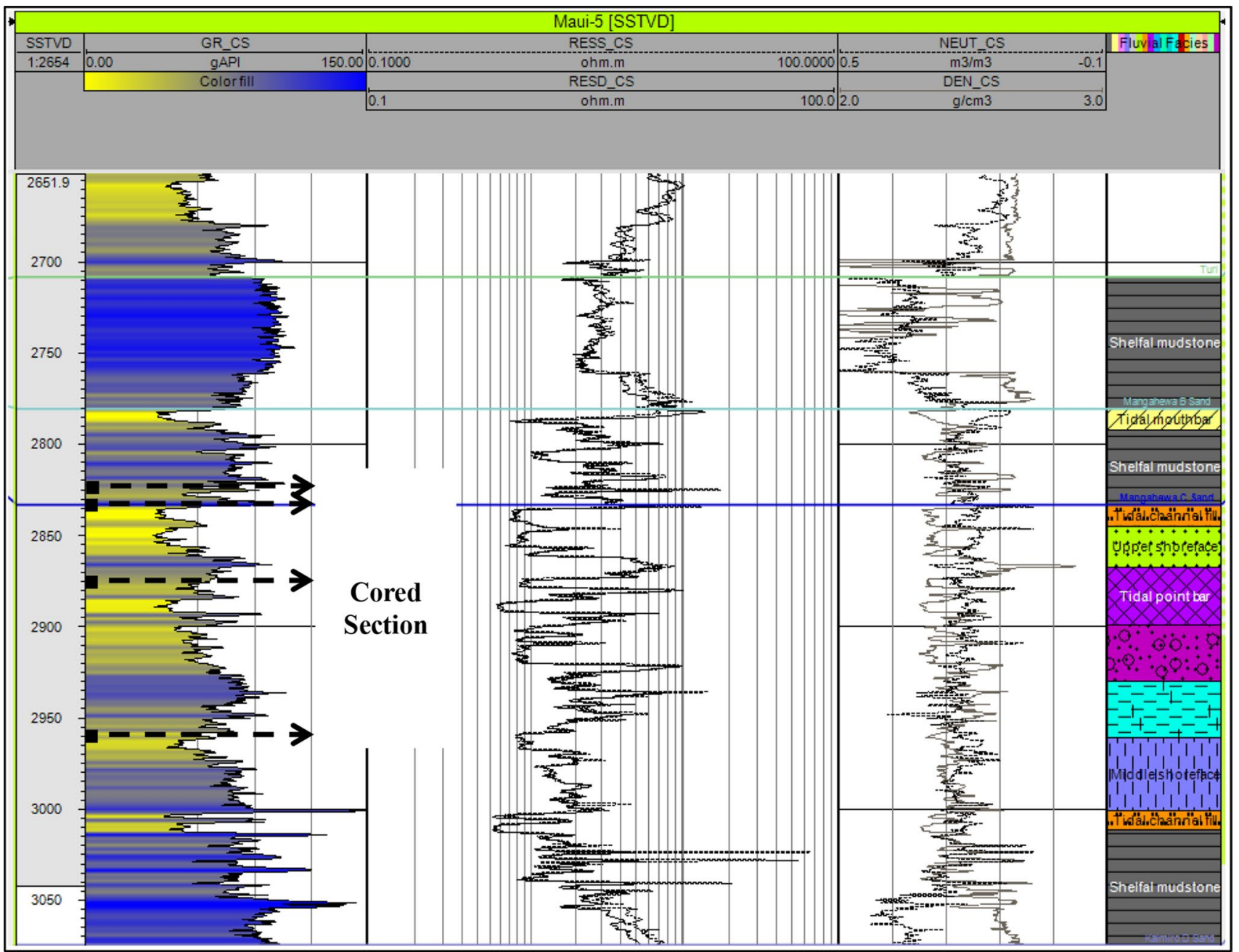

Fig. 7 Cored and uncored sections of the Maui-5 well. It is to be noted that the depositional facies interpreted for this well is based on the log-based lithological interpretation, probability of depositional facies occurrence. Initially, the cored sections are interpreted, calibrated and then correlated with the uncored sections for generating the depositional facies model
According to the well log response and from the core photographs (Maui-5), it is evident that mouth bars have cleaner coarsening-upward response in the southern area compared to the wells in the northern area. Evidence of lack of bioturbations is also present in the core photographs (Figs. 10, 11). For our study, mouth bars that are seen in $\operatorname{logs}$ and cored photographs are all thought to be tide-dominated. Similar observations were made by Nicoletta et al. (2012) and Edmonds (2012) in siliciclastic basins of similar stratigraphic setup. We also identified similar tidal mouth bar facies in Maui-2, Maui-5 and Maui-1 wells (from north-central to south).

\section{Tidal flats}

Tidal flat facies in Maui well logs are identified as very fine to fine-grained sandstones with relatively higher gamma response (Fig. 10). In the study area, average thickness of the tidal flat successions is about $20-50 \mathrm{~m}$ in different wells. Core photographs of the Maui-5 well have shown flaser to lenticular-bedded, wavy-bedded siltstone/sandstone and parallel-bedded very fine to fine-grained sandstone with minor bioturbations, ripple marks and irregular stratifications (Fig. 12). It is to be noted that tidal flats are intertidal, soft sedimented deposits which are normally found between high-water and mean low-water spring tide datums (Dyer et al. 2000) and are generally located in estuaries and associated low-energy marginal marine environments. Mudflat, mixed flat and sandflats are extensively studied by Cacchione et al. (2002) and Pritchard et al. (2002) that were based on grain size distributions and changes in facies.

Muddy and sandy units are generally repeated in vertical section too as shown in Figs. 12 and 13. Reactivation 


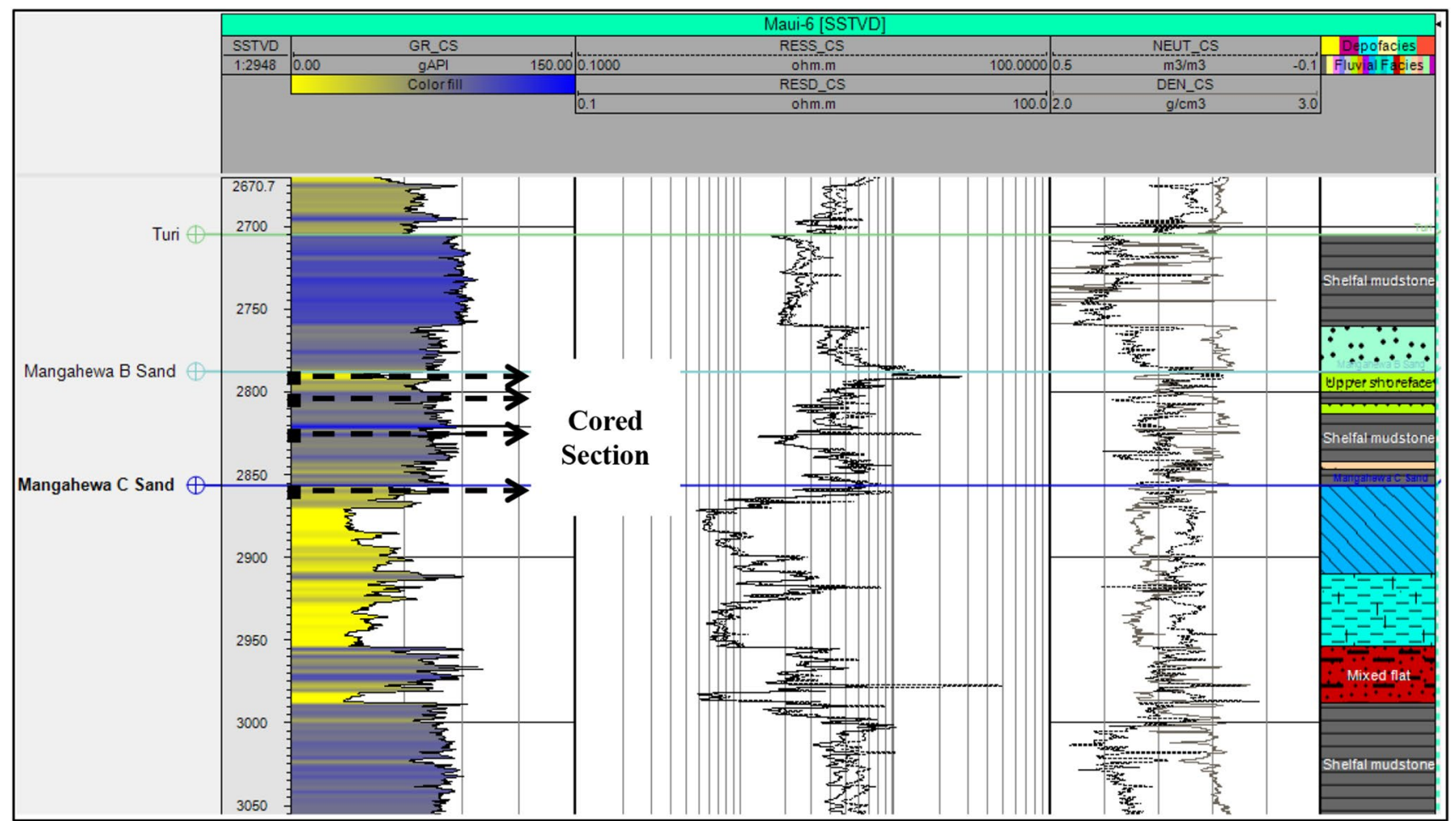

Fig. 8 Cored and uncored sections of the Maui- 6 well. Cored sections are initially interpreted, calibrated and then correlated with the uncored sections for generating the depositional facies model

surface and mudstone rip-up clasts are well preserved within the sandstone (Desjardins et al. 2012; Carmona et al. 2009; Shanmugam et al. 2000; Pashin et al. 2004). Reactivation surfaces seen in the well logs of Maui-5 well are typically indicative of varying flow directions (Fig. 13). Mudflats, sandflats and mixed flats occur in all wells and in different depths except Maui-5. It is evident that mudflats occurring within the Maui wells occur mostly toward the intertidal zone, whereas mixed and sandflats occur toward the supratidal zone. Mudflats encountered in wells have fining-upward successions in well logs, whereas mixed to sandflats have upward-coarsening trends as seen in the wells. The main difference for separating mudflats from sandflats is the subtle increment of GR value in mixed mudflats (Emery and Myers 1996) compared to that of the sandflats (Fig. 13).

\section{Lagoonal mudstone}

Lagoons are typically characterized by broad tidal flats (Plint et al. 1992). The succession is typically mudstone, often with thin wave rippled sand beds (Boggs 2011). Identifying lagoonal mudstone can be challenging at times, but we have identified that lagoonal mudstones occurred with the occurrence of shoreface/barrier sands above or below in the studied wells (Fig. 10). Therefore, the association provided critical insight to determine this particular depositional environment. Lagoonal mudstone facies occurred in Maui-7 and Maui-1 wells which sit relatively on the southern area (landward) of the studied formation (Fig. 14).

\section{Tidal creek/channel fill/point bar}

Tidal channel fill deposit comprises of well-sorted, fine- to medium-grained, herringbone cross-bedded sands and forms a fining-upward sequence as seen in the well log response and core (Maui-5). Except for Maui-6 and Maui-3 wells, all other wells encounter tidal channel fill deposits (in different depth levels as well suggesting of repetition of channel fill deposits in time), occasionally with channel lag at the base of the channel (Fig. 10). Pebbly sandstone is found at the base of the core within the facies association. The channel deposits are relatively small, stacked channel sand bodies (Fig. 15), representing repeated cut and fill. These sand bodies show low gamma values and narrow N-D separations in both core photographs and logs.

Tidal point bars encountered within the formation are aggraded to fining-upward channel fills representing subtidal deposits that form in the middle to inner portions of estuaries. Tidal point bars occur in different depth levels within the Maui wells except in Maui-6 and Maui-3. Point 


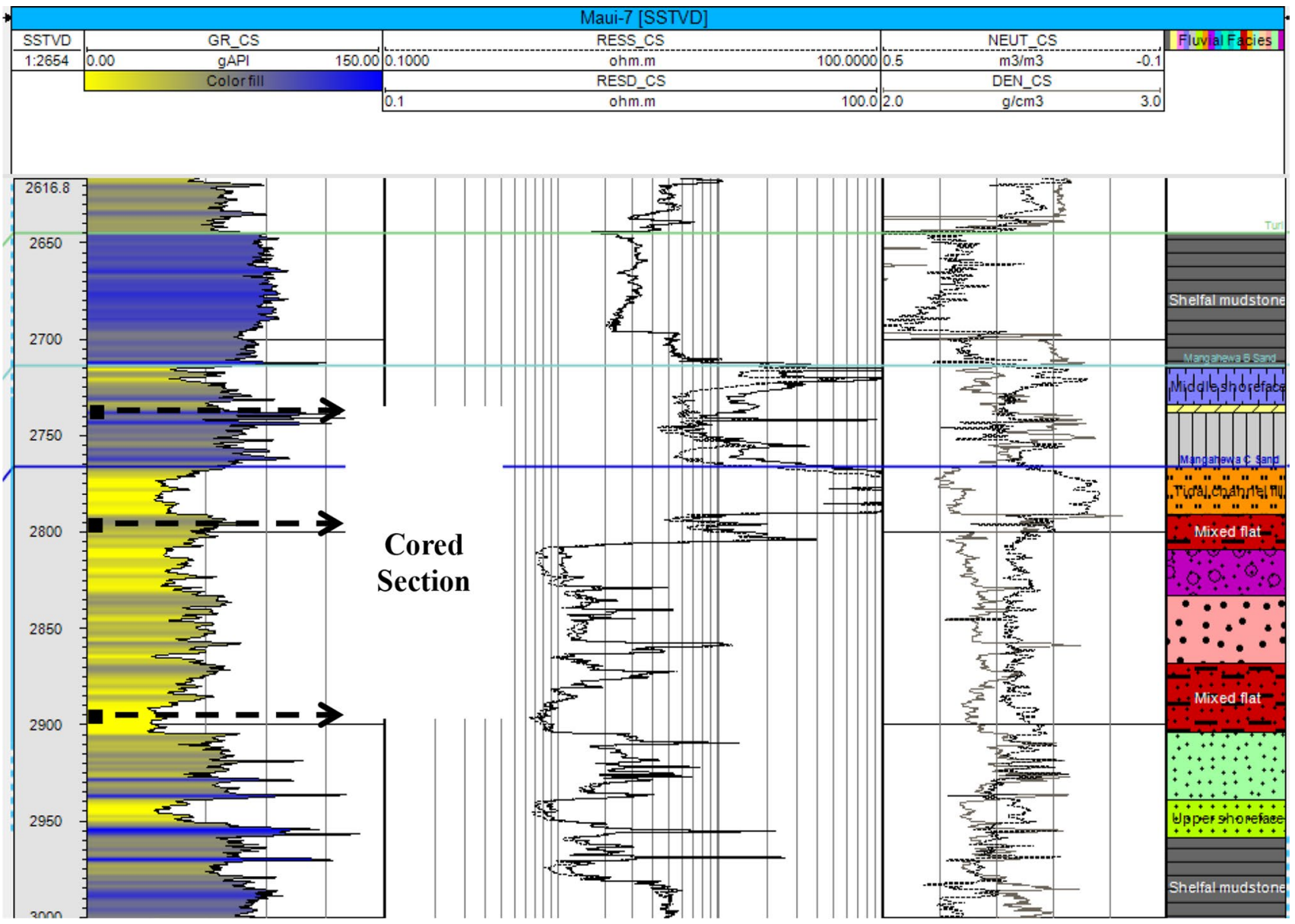

Fig. 9 Cored and uncored section of the Maui-7 well. Representative samples are taken from different depths of the Mangahewa Formation for a wide coverage on the depositional facies distributed over the

bar deposits in Mangahewa reservoir are normally finingupward sequences, mostly restricted to the areas where the tidal channels have formed.

\section{Restricted bay sand}

Restricted bay sands are highly argillaceous and heavily bioturbated sandstones interpreted in the Maui-5 well (Fig. 16). Restricted bay sands gradually fill with sediments deposited in a series of prograding mini-deltas and are normally associated with tidal channel fronts where the grains get sorted and get deposited while protruding from the delta into the marginal marine conditions (Abrahim et al. 2008). These facies show relatively higher GR values compared to that of the tidal flat deposits (Abrahim et al. 2008). It has fining-upward succession with medium-grained sandstone at the base. In Maui-6 it is associated with tidal channel fill deposits. studied well. Initially, the cored sections are interpreted, calibrated and then correlated with the uncored sections for generating the depositional facies model

\section{Estuarine distributary channel sand}

Estuarine forms at the mouth of the river flowing into the sea. Estuarine distributary channel sand deposition is very closely associated with barrier beach deposits. It is encountered only in Maui-3 which is on the northern area of the reservoir. Relatively thick channelized sand body is interpreted as estuarine channel sands (Figs. 10,17), characterized by low API gamma response, blocky, upward-fining profile and wide separation in Neutron-Density (N-D) log (Abrahim et al. 2008; Rahmani 1988). It encounters a very thick succession of estuarine sand of about $160 \mathrm{~m}$. In Maui$\mathrm{B}$ (P8), bioturbations are generally absent due to high-energy environment. 

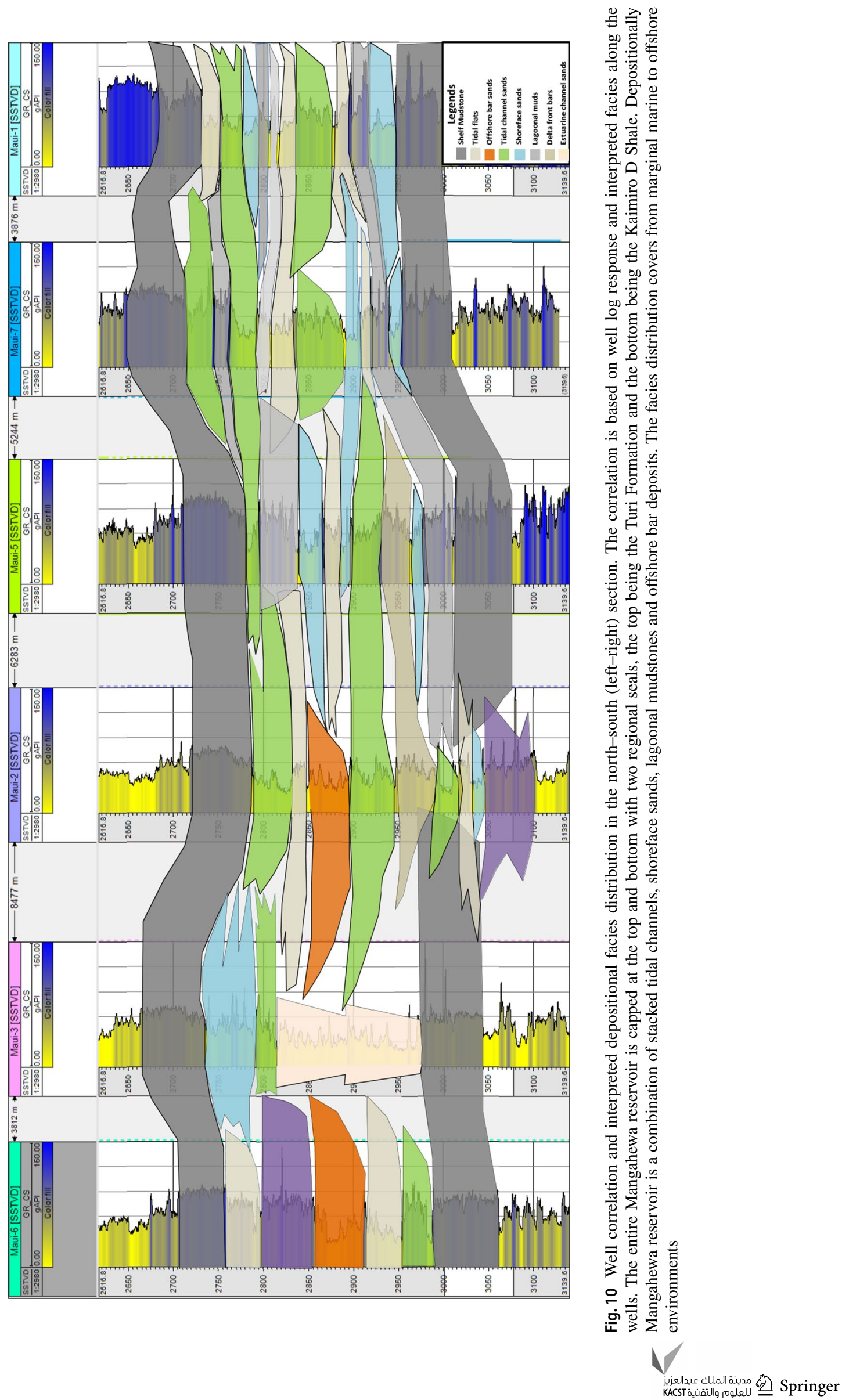


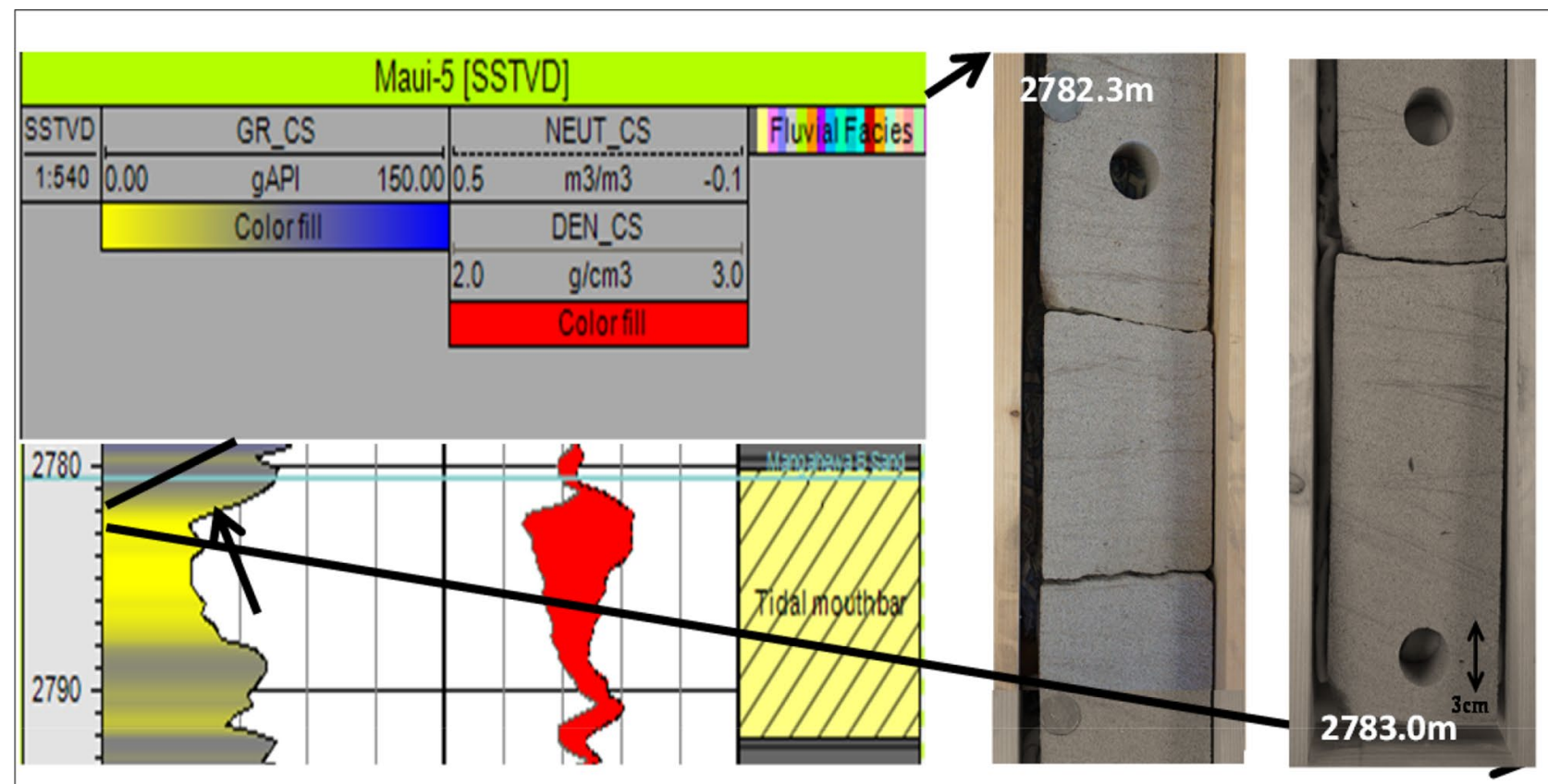

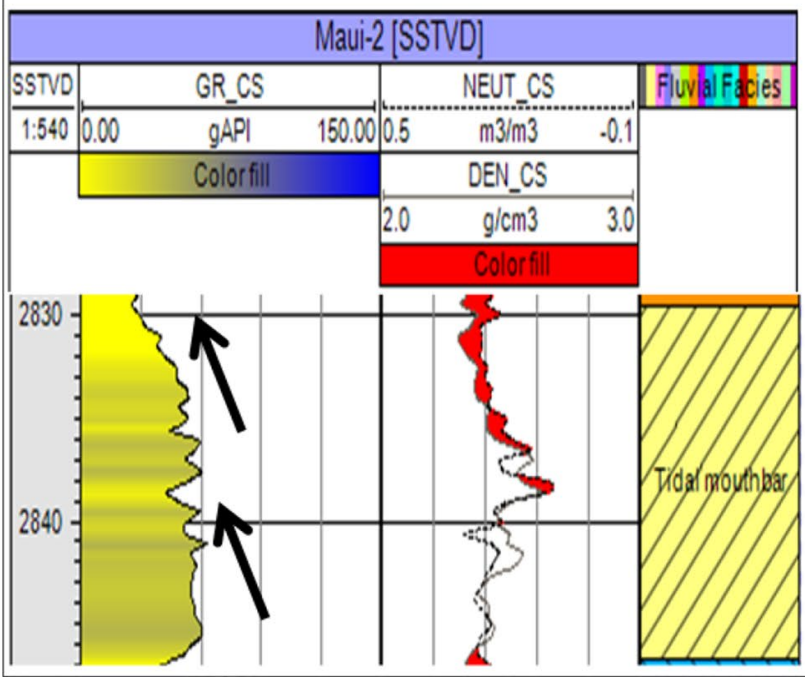

Fig. 11 Tidal mouth bar response (coarsening-upward cycles) in core and log of Maui-5 well (top), Maui-2 and Maui-1 (bottom). Moderate- to well-sorted sands with cross-bedding are present in the core. Log response displays variations in GR because of varying sand

\section{Distribution}

Marginal marine facies are commonly identified as heterolithics in character. Marginal marine facies are spreaded across the paleoshore of the Upper Eocene deposits. Wells encountering this facies association are Maui-3, Maui-5, Maui-6 and Maui-7.

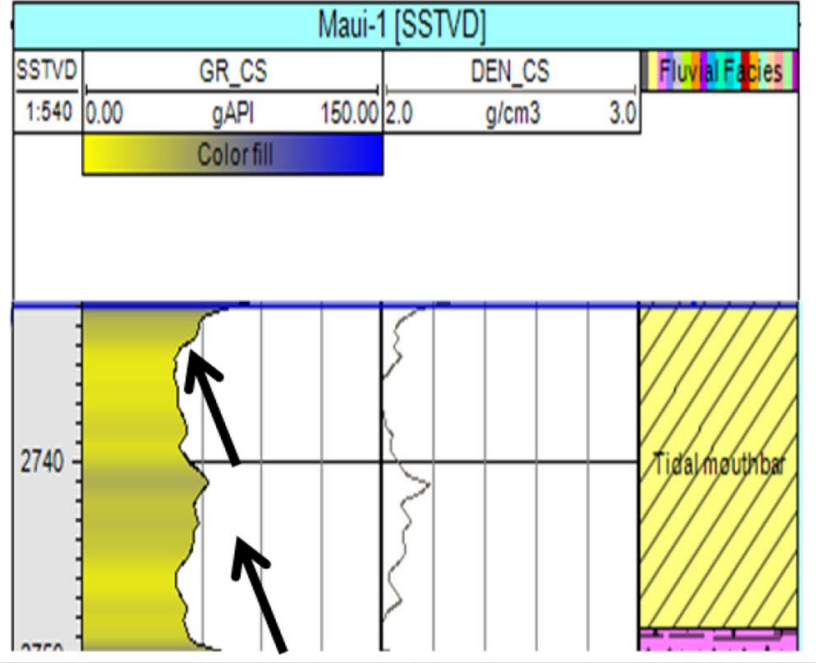

thickness with a gradational contact. At the base coarsening-upward cycles are interpreted in the Maui-2 and Maui-1 wells (bottom) that are solely based on log response as no cores are available in these wells

\section{Shallow marine facies association}

For this study, we have interpreted shallow marine environment, i.e., shoreface depo-facies, from upper to lower shoreface (from the mean low-water mark to mean fair weather wave base) (Howell et al. 2008). Shoreface environments are commonly characterized by fairly thick, upward-coarsening cycles representing prograding facies from mud-dominated 


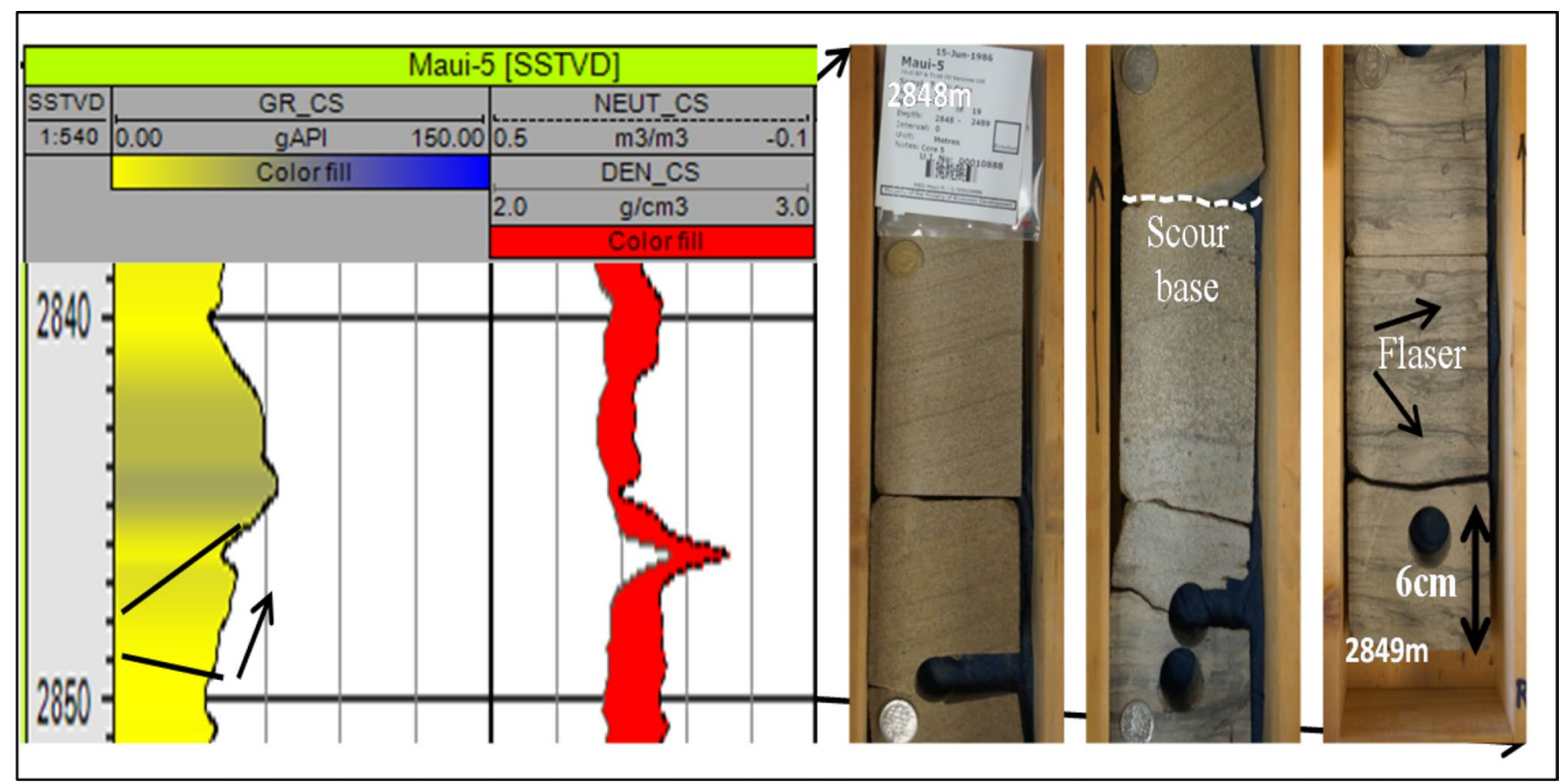

Fig. 12 Tidal-flat response in core and well log of Maui-5 well. Log response indicates typical fining-upward cycle of the tidal channel fills. Rhythmic-bedded mudstone and siltstone, flaser to lenticularbedded and parallel-bedded very fine to fine-grained sandstone is observed on the cores. Flaser beddings are also observed at the bottom of the succession indicating the presence of bidirectional flows of a typical tidal facies association

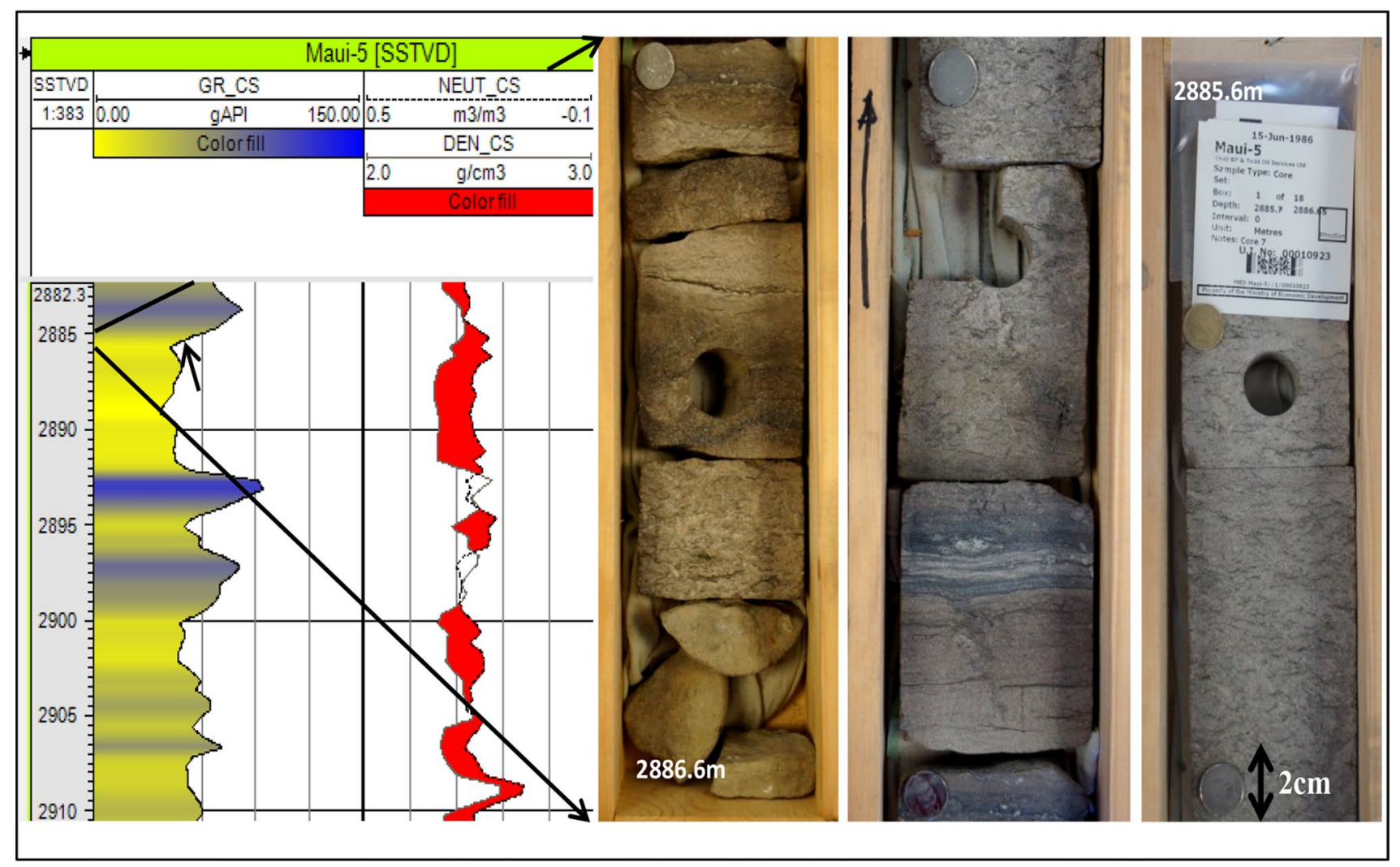

Fig. 13 Sand flat facies interpreted in well logs and core photographs of Maui-5. Well log response is suggestive of upward-coarsening successions. The core image of Maui-5 (R) indicates mud drapes within the sand beds, sigmoidal cross-bedded sandstone and absence of bioturbations 

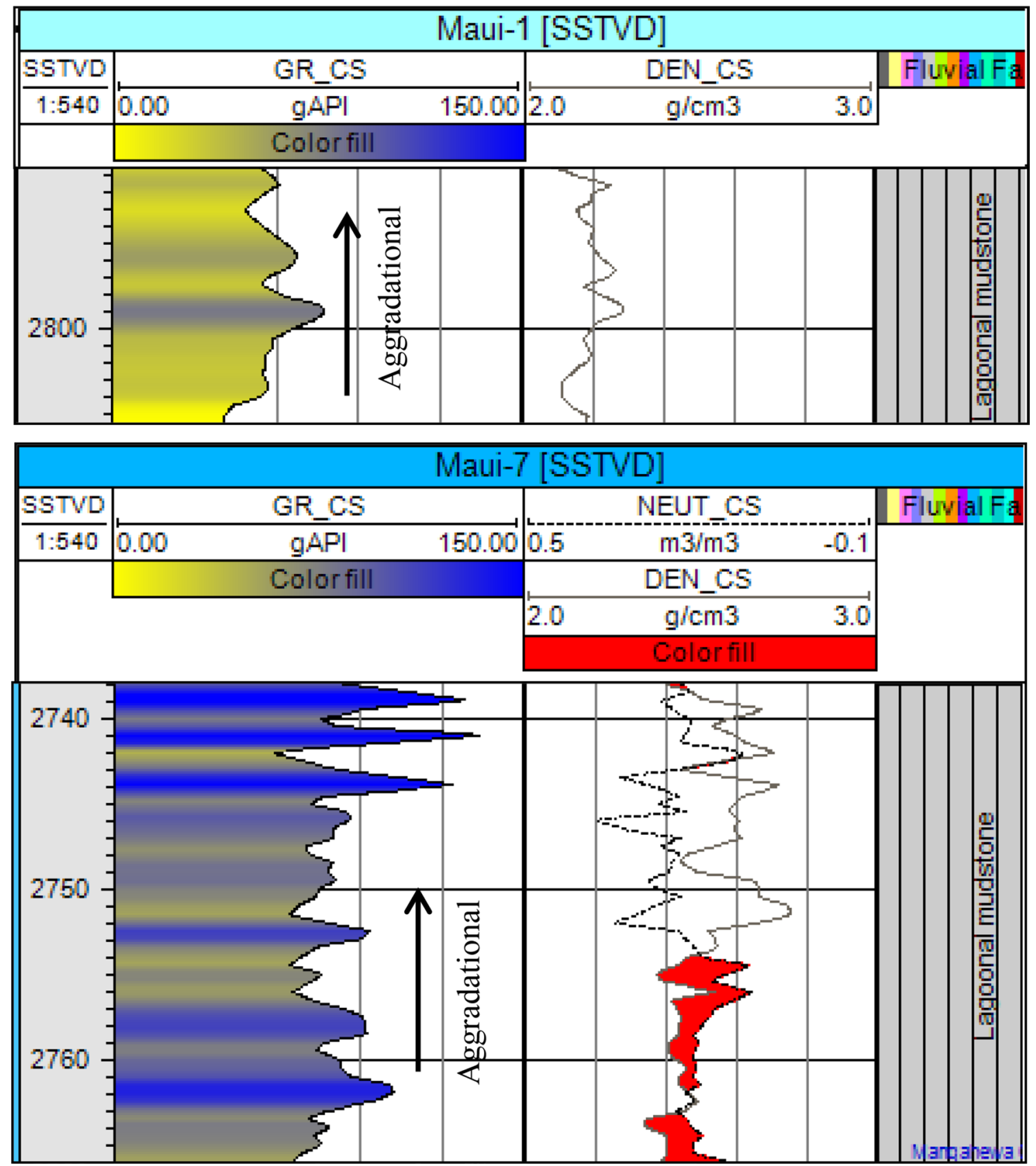

Fig. 14 Lagoonal mudstone response is interpreted in Maui-1 and Maui-7 wells. Serrated log response indicates fluctuating low-energy lagoonal mudstone associated with very fine-grained sand-silt intercalation in Maui-7 well

offshore through lower shoreface and upper shoreface sandstones. Therefore, we employed the method of gamma ray response and relative abundance of sand versus shale to separate upper shoreface sands with middle to lower shoreface sands (Fig. 10).

\section{Upper shoreface}

The thickness of the facies interpreted both in logs and in core slabs ranges from 10 to $30 \mathrm{~m}$, consisting of parallelbedded, low-angle cross-bedded sandstone, minor bioturbated sandstone. The thickness of the siltstone and fine sandstone layers ranges from few $\mathrm{cm}$ to several meters, which are characterized by well-sorted low-angle cross-bedded 


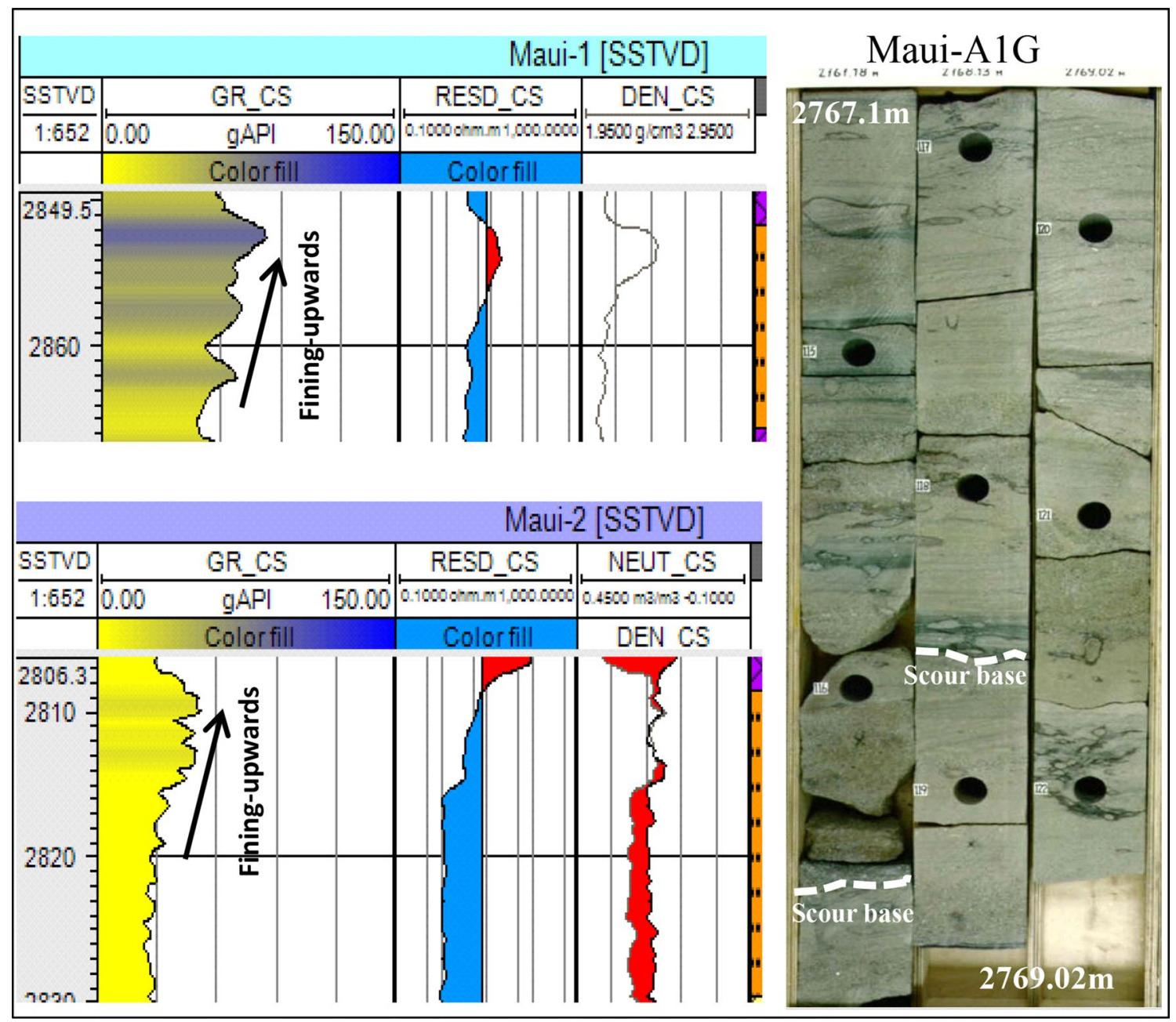

Fig. 15 Stacked channel deposits in Maui-1 (mud-dominated) and Maui-2 (sand-dominated) and Maui-A 1G. In the well logs of Maui-1 and Maui-2 (L), stacked channel deposits show a fining-upward, seasonal fluctuating successions. On the right, the cores of Maui-A 1G show fine- to medium-grained cross-bedded sandstones with several

sandstone. Upper shoreface facies consist of relatively cleaner sandstones where sands are mostly brought by the longshore drift and occasionally subjected to reworking by tidal, wave or storm actions (Li et al. 2011; Boggs 2011; Allen and Johnson 2010; Helland-Hansen 2010; Reineck and Singh 1980). In well log response, upper shoreface is observed to have thicker upward-coarsening gamma ray log response and wavy-bedded siltstone/sandstone. Similar studies were made by Li et al. (2011) and Cross et al. (1993) in two different siliciclastic basins. We also identified Ophiomorpha burrows within the cores (Fig. 18) which is highly indicative of upper shoreface environment of deposition (Hammer et al. 2010; Howell et al. 2008). scour bases suggesting stacked channel occurrence within the cored sections. Presence of trace fossils such as Planolites and Ophiomorpha (bioturbation on the channel tops) is suggestive of decrease in energy accompanied by possible marine incursion

\section{Middle/lower shoreface}

Middle and lower shoreface sands are characterized by the relative abundance of argillaceous sediments and intense bioturbations. For middle shoreface sands, sand packages are comparatively thicker as seen in the wireline logs and cores (Fig. 19) within overall aggradational packages. However, lower shoreface sands are highly argillaceous and intensely bioturbated with high gamma values and upward-cleaning API response. 


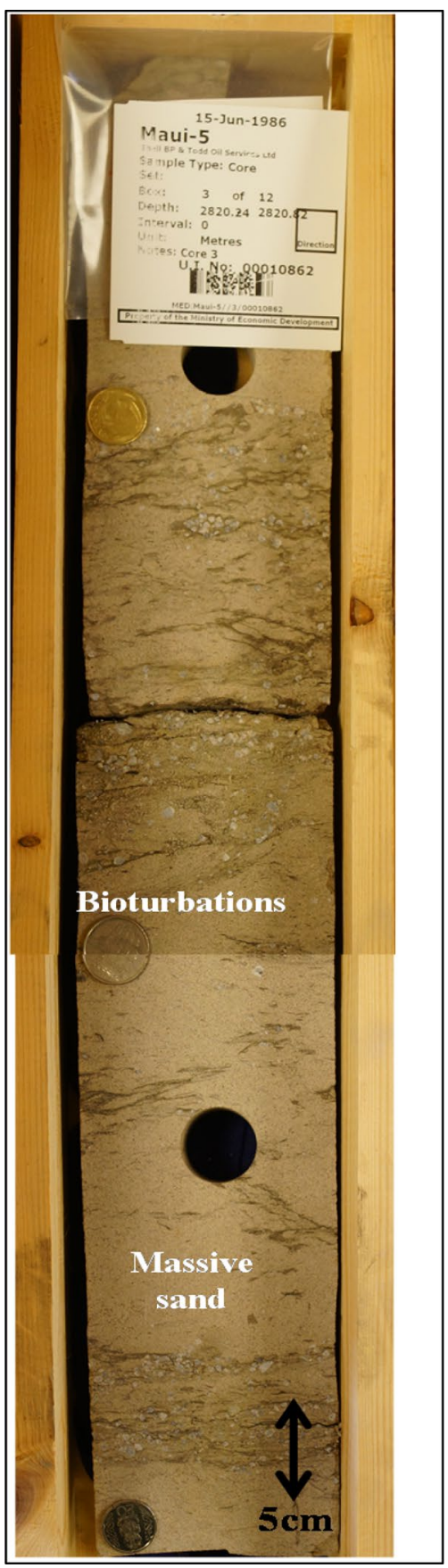

Fig. 16 Bay facies are normally overlain and underlain by the marginal marine channel sandstones in the Maui-5 well

\section{Distribution}

The presence of the shoreface sands is common throughout the Mangahewa reservoir succession in the Maui Gas Field.
We have observed that shoreface facies occur mostly in the northwestern part of the field where the facies are relatively thicker.

\section{Offshore facies association}

\section{Shoreface barrier sand/reworked offshore bar}

Shoreface barrier bar sands have been observed and interpreted in the logs (Fig. 10) and core photographs. Rare occurrence of medium- to coarse-grained sands is interbedded within the shelfal mudstone, which is interpreted as possible shoreface barrier sands (Fig. 20).

\section{Shelfal mudstone}

Shelfal mudstone is a very fine-grained facies deposited from suspended sediments. Consequently, the massive mudstone and silty mudstone are suggestive of low-energy stable conditions mainly found in the offshore facies associations. Shelfal mudstone is encountered (Figs. 10, 21) in most of the Maui wells and on top of the Mangahewa reservoir suggesting of a regional seal over the entire formation. This facies is interpreted to extend beneath the fair weather wave base. The predominant lithology seen in the $\log$ s indicates high gamma response from the mudstone with upward-cleaning cycles (Miall 2016) having laminae and thin beds of lenticular, very fine sandstone and associated burrowing.

\section{Distribution}

Offshore facies are common in the northern end of the facies model, whereas it is also seen within the central eastern part of the model indicating possible transgression of the offshore facies toward the land.

\section{Distribution of facies association based on thin-section petrography}

Mangahewa Formation in terms of suitable depositional facies for potential reservoir quality was interpreted to a range from poor to excellent.

Grain size of the Mangahewa Formation sandstones is generally favorable to good reservoir quality, with common medium-grained sandstones; coarser- and finer-grained 
Fig. 17 Estuarine log response observed in Maui-3 (L) and core photograph of Maui-B P8 (R). The $\log$ response is relatively cleaner throughout the entire interpreted succession (L). On the right, the cored sections of Maui-BP8 show tidally influenced estuarine channel sands with clean, generally medium-grained, upward-fining, cross-stratified sandstone.

The beds are interpreted to be stacked, and bioturbations are not present due to higher energy environment of deposition

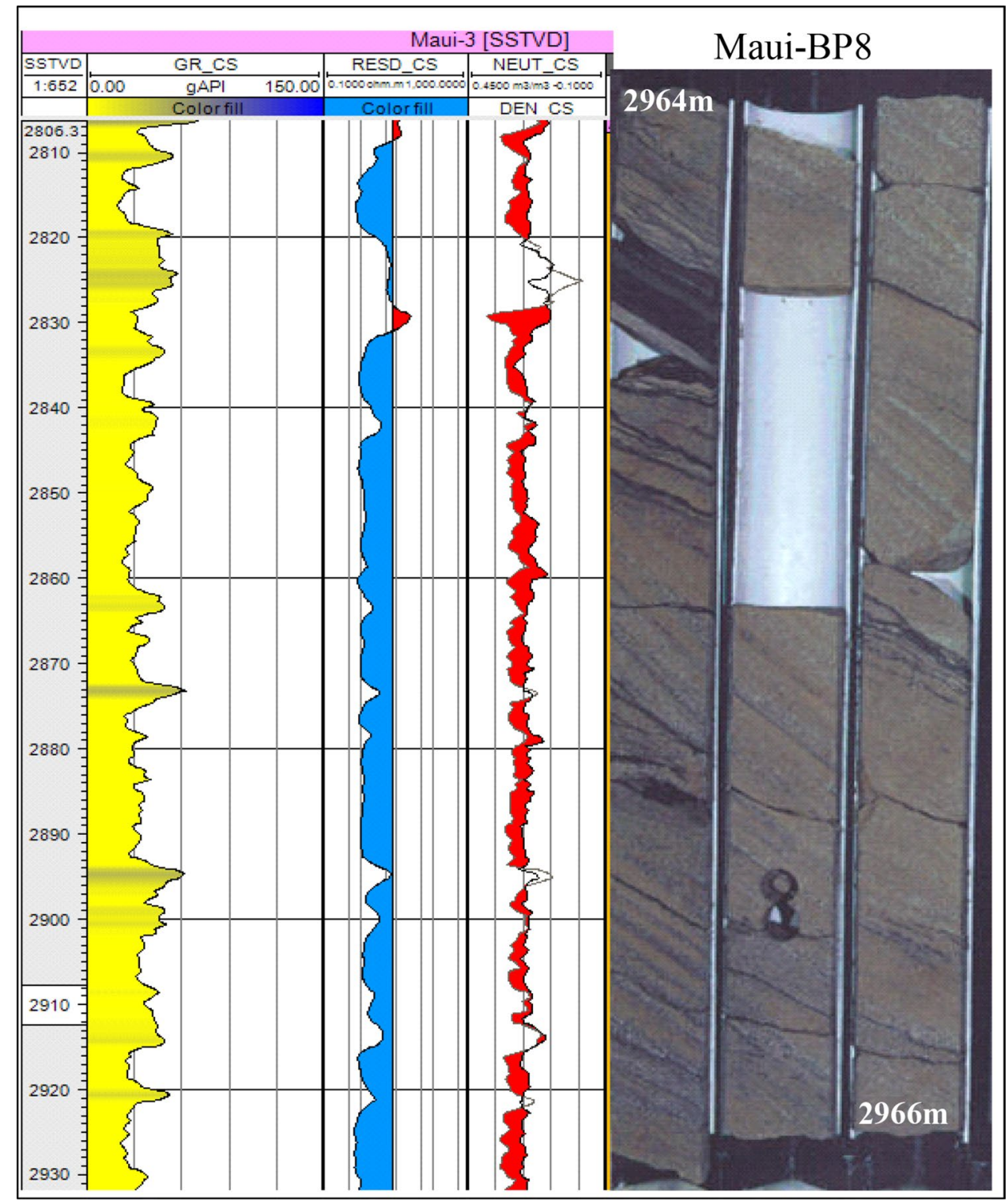

sandstones also occur and are dependent on the facies. Sorting characteristics are highly variable (poor to good) and are also dependent on facies, commonly with the best sorting occurring within the coastal sand bodies (shoreface sands). These observations indicate that the coastal sand bodies may have the best reservoir potential, exclusively based on texture alone.

Petrographic examination of the Mangahewa Formation sandstones shows them to be composed dominantly of quartz and feldspar with very rare lithic fragments. This highly rigid/labile grain ratio is typically favorable to preservation of intergranular porosity. However, variable amounts of detrital matrix, compacted and altered mica grains do occur particularly within the coastal plain facies; both of these might be detrimental to reservoir quality.

The main detrimental factors to reservoir quality of the Mangahewa Formation are the effects of compaction and cementation during burial diagenesis, which is clearly evident in the studied thin sections along the Mau-5 and Maui- 6 wells (Fig. 22). Carbonate cement is locally pervasive, but more commonly quartz cements occur; both mineral cements have reduced the size of intergranular pores and in some cases have removed all traces of visible porosity. 


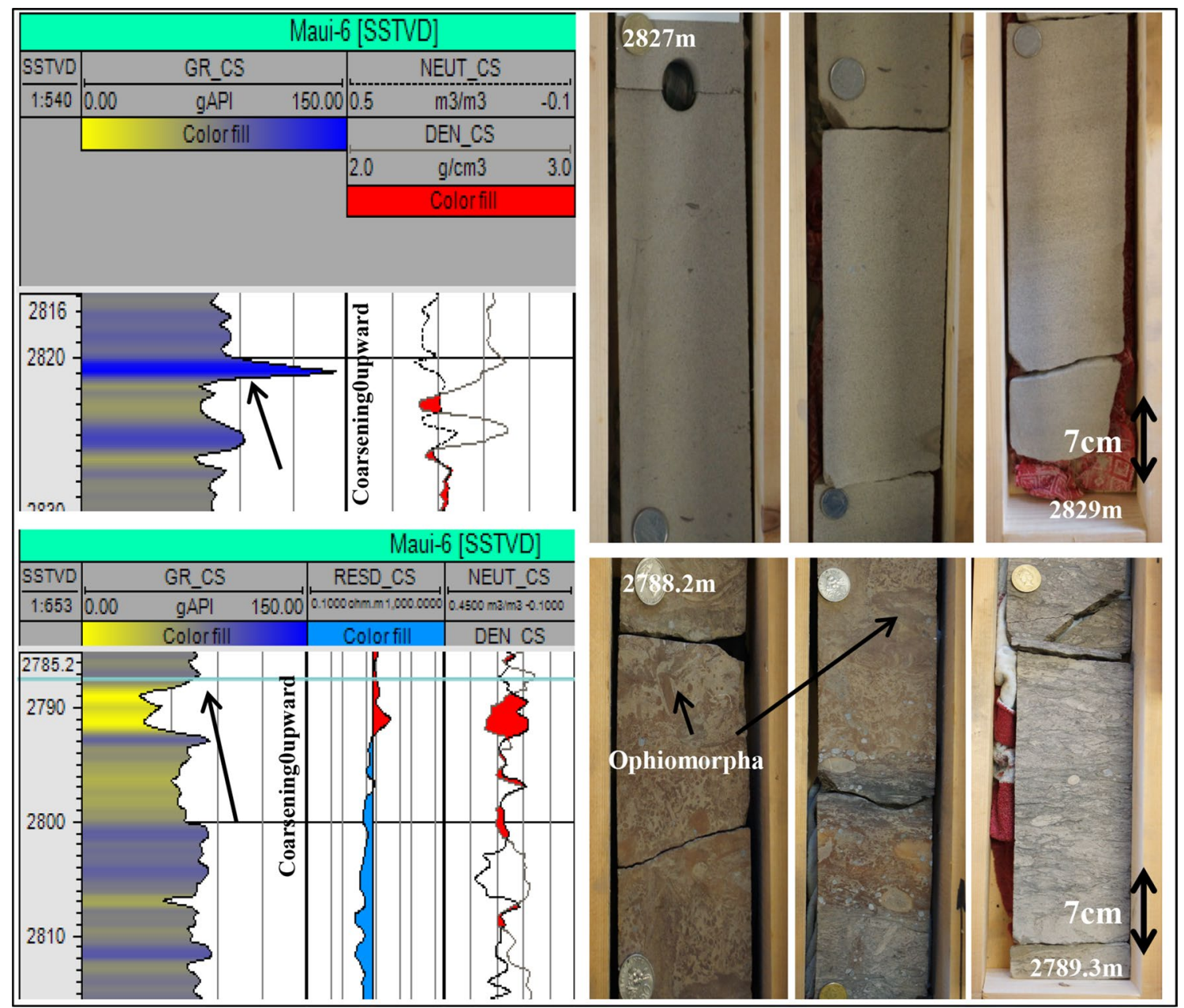

Fig. 18 Upper shoreface deposits interpreted in Maui-6 well. Core images interpreted on two different depth ranges (2827-2829 and $2788.2-2789.3 \mathrm{~m}$ ) are interpreted to be upper shoreface sands. Fairly thick interval of clean sandstone (upper right) associated with occa-

\section{Stochastic modeling of Mangahewa reservoir}

In recent years, stochastic modeling has been a significant tool for addressing complex problems related to geosciences (Pyrcz and Deutsch 2014; Myers 2006). In short, stochastic modeling is a quantitative description of a natural phenomenon which predicts a set of possible outcomes weighted by their likelihoods or probabilities (Karlin and Taylor 1998). It is widely used to build probabilistic geomodels of petroleum reservoirs conditioned on variety of information like seismic, core porosity-permeability, well log responses (Goovaerts 2006). The advent of stochastic modeling and the development of the modeling parameters have been considered sional low-angle laminations (lower right) indicates typical shoreface sands. Lower right core images show the presence of Ophiomorpha at the top of the succession, possibly deposited in the shoreline barrier system

as the key factors for the current study to utilize stochastic modeling in the Mangahewa reservoir. Sequential indicator simulation (SIS) is a widely used technique in industry for its categorical variable models; therefore, we have opted for the algorithm for modeling Mangahewa facies within Maui Gas Field. Although there remain several legitimate criticisms against SIS, such as the produced model can appear to be patchy, variograms can control two-point statistical measures, cross-correlation between multiple categories is not explicitly controlled, etc., we however opted for the algorithm for some specific reasons for which SIS is chosen over any other conventional techniques (Deutsch 1998). With SIS, required statistical parameters of the facies are easy to infer from limited data, the model is reasonable in settings, 
Fig. 19 Middle shoreface deposits interpreted in the cored sections along with the log responses seen in the Maui-5 well. These are slightly to moderately argillaceous sandstones with heavy bioturbations seen the cored sections (R). The sandstones of the middle shoreface are generally medium-grained representing high-energy deposition. Burrows seen in the cores are predominantly bigger in size, thick-walled Ophiomorpha, with other possible burrows including skolithos, planolites

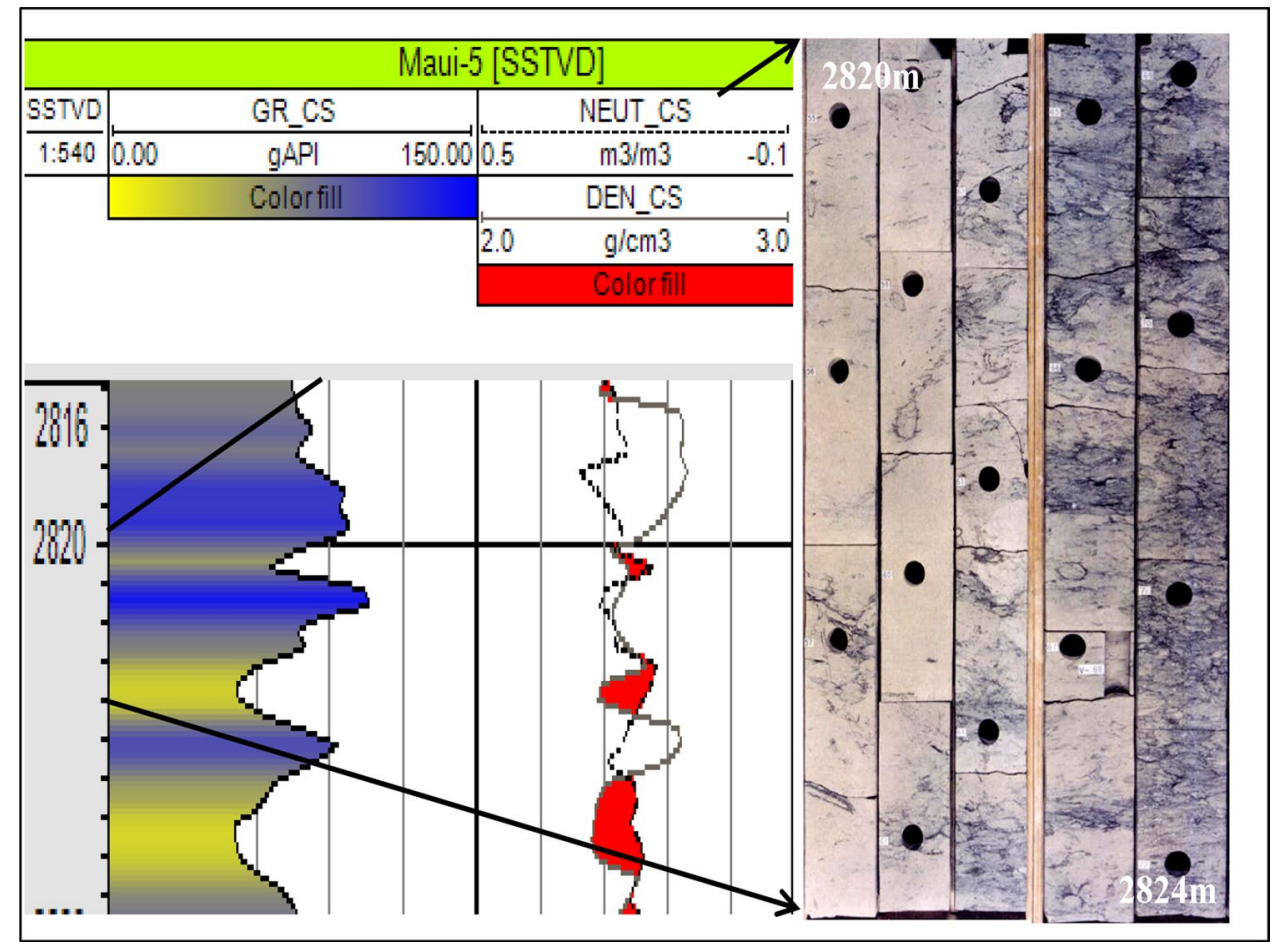

and the algorithm is robust providing straightforward way for transferring uncertainty in categories through resulting numerical models (Pyrcz and Deutsch 2014; Deutsch 1998).

\section{Probability of facies occurrence}

For Mangahewa reservoir, eighteen (18) depo-facies were identified. These facies account for a set of particular depositional environment and are further grouped into three broad facies associations (Table 2). The actual occurrence of a particular facies interpreted on the logs is maintained across the gas field in all available wells and is manually picked following the log motifs seen from the log response of the studied wells to determine facies and associated depositional environments. The variability of the facies depends on the paleodepositional structure, geological conditions, local sea level fluctuation and sedimentation rates. Similar approach was made by Catuneanu et al. (2009) for probability occurrence of facies classes in different stratigraphic zones.

Analyses of the depo-facies distribution and the probability statistics using modeled data analysis (MDA) with all possible wells, indicate that estuarine channel sands (32\%), shoreface sands and tidal channel fills (44\%) are the most frequent facies according to the probability distribution within the model, whereas shelfal mudstone constitutes only $7 \%$ of the total facies. Depo-facies modeling also shows that within marginal marine (MM) environment, tidal channel fill, point bar and mouth bar sands occupy $28 \%$ of cells within the facies model and tidal flats (sand flat/mixed flat/mudflat) constitute $10 \%$ of cells, whereas estuarine channel sand dominates with $26 \%$ of cells on the modeled reservoir. We also have observed that over $90 \%$ of the interpreted facies have $10-20 \mathrm{~m}$ of thickness (Fig. 23). It is to be noted that while generating the model, facies classes, their possible occurrence in logs (Harding et al. 2004; Bloch and Helmold 1995) and distribution in present-day morphology are taken into consideration for both horizontal and vertical direction. Of the shallow marine (SM) facies, shoreface sands comprise about $21 \%$ and offshore bar sands comprise $8 \%$ of the total facies modeled in the reservoir. It is evident from the estimates that the model gets close to approximation when compared with the facies probability occurrence calculated from the actual well responses.

Marginal marine is the dominant paleoenvironmental setup of the Mangahewa reservoir having $64 \%$ of depofacies. Shallow marine environment comprises about $29 \%$ of the depo-facies, and the offshore constitutes only $7 \%$ of the facies distributed within the gas-water contact (GWC). While optimizing model realizations, the probability curves of the facies have shown low degree of separation from the actual data interpreted in the well logs (Fig. 24). 


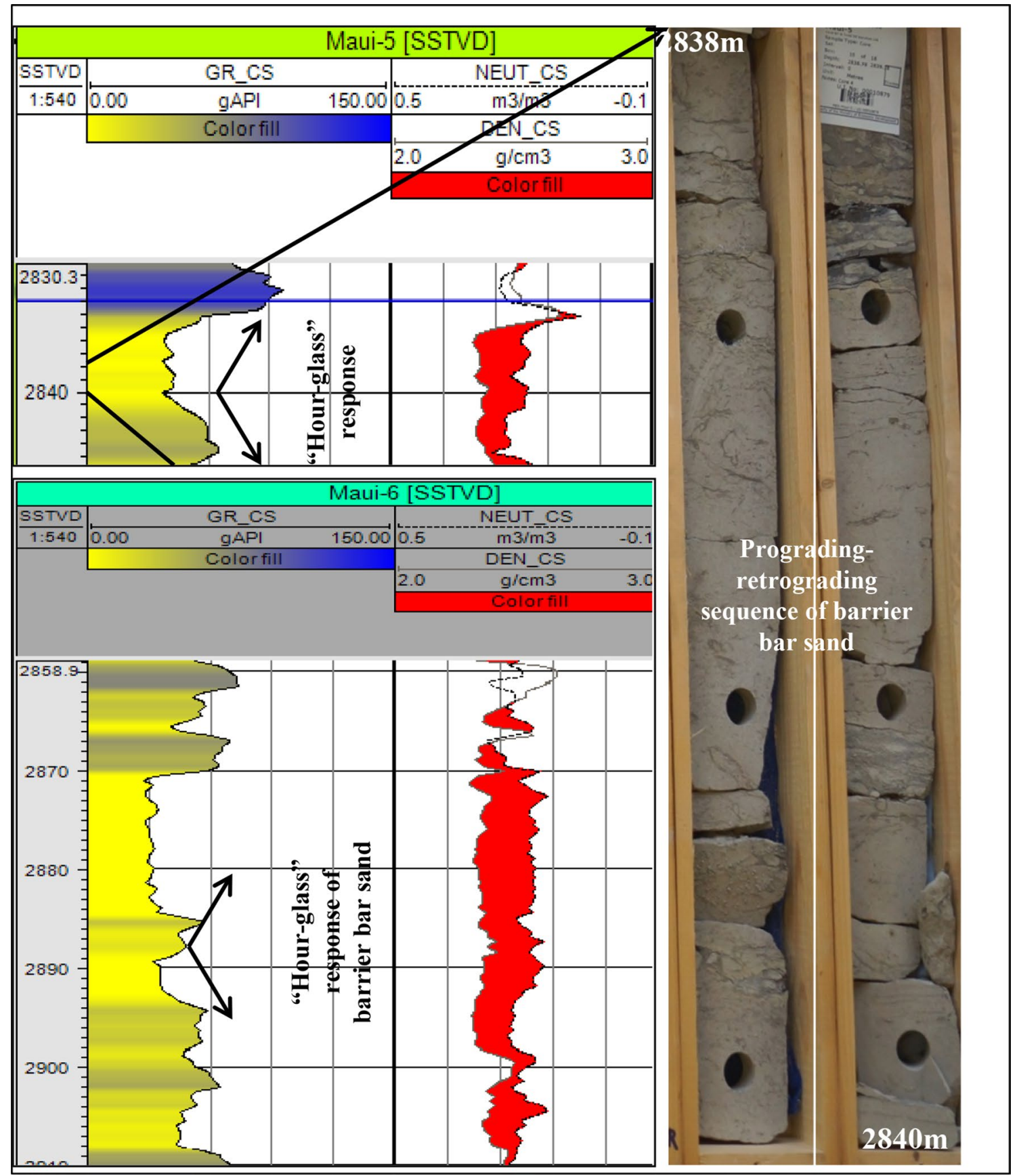

Fig. 20 Barrier-bar sand/reworked offshore bar sand log/core responses interpreted in Maui-5 core (2838-2840 m) and Maui-6 well. Barrier bar sands are interpreted as thickly bedded sandstone,

\section{Facies dimensions}

Determining three-dimensional geometries of the interpreted facies was a key component of this study. As the facies and facies classes were directly associated with the quality of the reservoir, facies geometries were carefully interpreted. According to the facies associations, tidal flats, low-angle laminations possibly representing remnant hummocky cross-stratifications (HCS) as seen in the cores (R)

tidal creeks/fill/point bars, lagoonal mudstone, bay sands and estuarine distributary channel sands were grouped in Marginal Marine Facies Associations, of which tidal flat is about $1-20 \mathrm{~m}$ in thickness in different gridded layers with an average width of 2000-3000 $\mathrm{m}$ in the model (Fig. 23). Tidal flats mostly occurred on the shallower layers of the model. Tidal creeks/fills/point bars combined were around 
Fig. 21 Offshore mudstone interpreted in Maui-6 well. Shelf mudstone is medium gray, silty and sandy mudstone characterized by irregular, ripple laminations. Log response is interpreted on the basis of very high GR value with negative separation on the N-D logs indicating water-wet muds of the shelfal mudstone (L). In the core, the shelfal mudstones are interbedded with very fine (storm) sandstones as seen in the core $(\mathrm{R})$

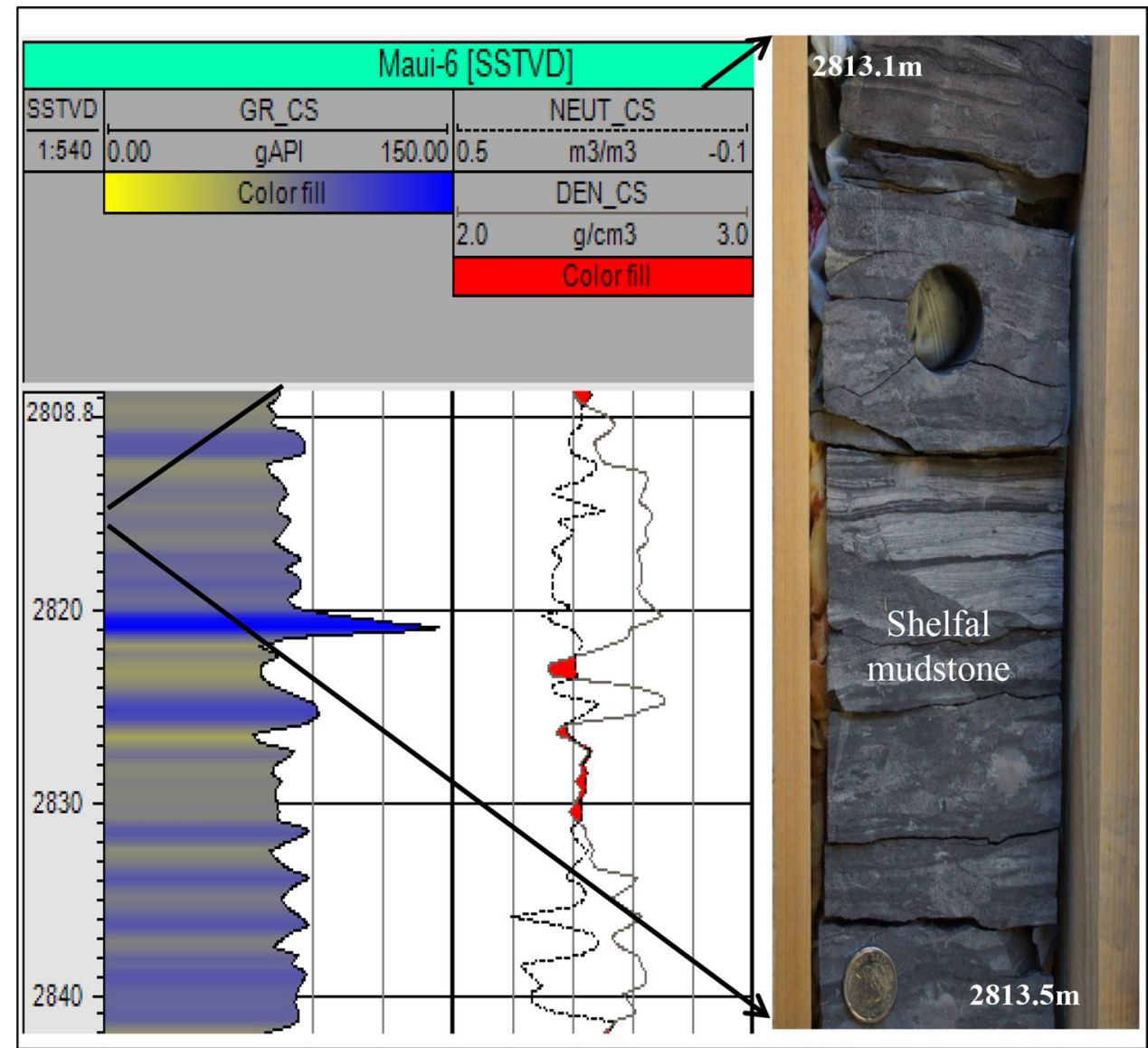

$10-15 \mathrm{~m}$ in thickness with an average width of 500-800 m in the model. Lagoonal mudstones were 1-10 m thick with an average width of 500-1000 $\mathrm{m}$ and occurred at the middle layers of the model. Bay sands were thinner, 1-5 $\mathrm{m}$ in thickness and restricted in width only within the shallow layers of the model. Estuarine channel sands were thicker deposits with an average thickness of 50-80 m within the shallower layers of the grid. It was interpreted to be found only on the northeastern and central section of the studied area. Upper, middle and lower shoreface of the Shallow Marine Facies Associations was found in the model with varying degree of thickness and width in different layers within the modeled grid. Upper shoreface was 5-30 m thick with an average width of 2000-5000 m distributed along the paleocoastline. Middle to lower shoreface is found to be $10-30 \mathrm{~m}$ thick on average and similar width that of the upper shoreface. These were found mainly on the mid-shallower layers of the model. Offshore mudstone is $10-50 \mathrm{~m}$ in thickness with an average width of 2000-10,000 m parallel to the paleocoastline and was found mainly on the shallower layers of the model (Fig. 23).

\section{Facies ordering}

The study area is part of a sedimentary environment that consists of marginal marine to shallow marine leading to the offshore environments. The entire facies associations are highly heterogeneous and complex. In this regard, all possible contacts and transition within depo-facies were taken into consideration for generating final stochastic facies model.

For this study, we first devised all possible strike and dip directions of all possible facies. Lateral geobodies and their vertical distributions were identified and generated using the appropriate algorithm mentioned above (Pyrcz and Deutsch 2014). Geobody is a term exclusively used for this study, which is defined as a specific geological body limited within a space in the subsurface significant enough to model in both horizontal and vertical directions (Strebelle et al. 2016). While modeling the facies for a particular ordering sequence, we have found that the facies proportion and association are roughly NE-SW oriented, whereas marginal marine facies are situated relatively on the SW part and the 

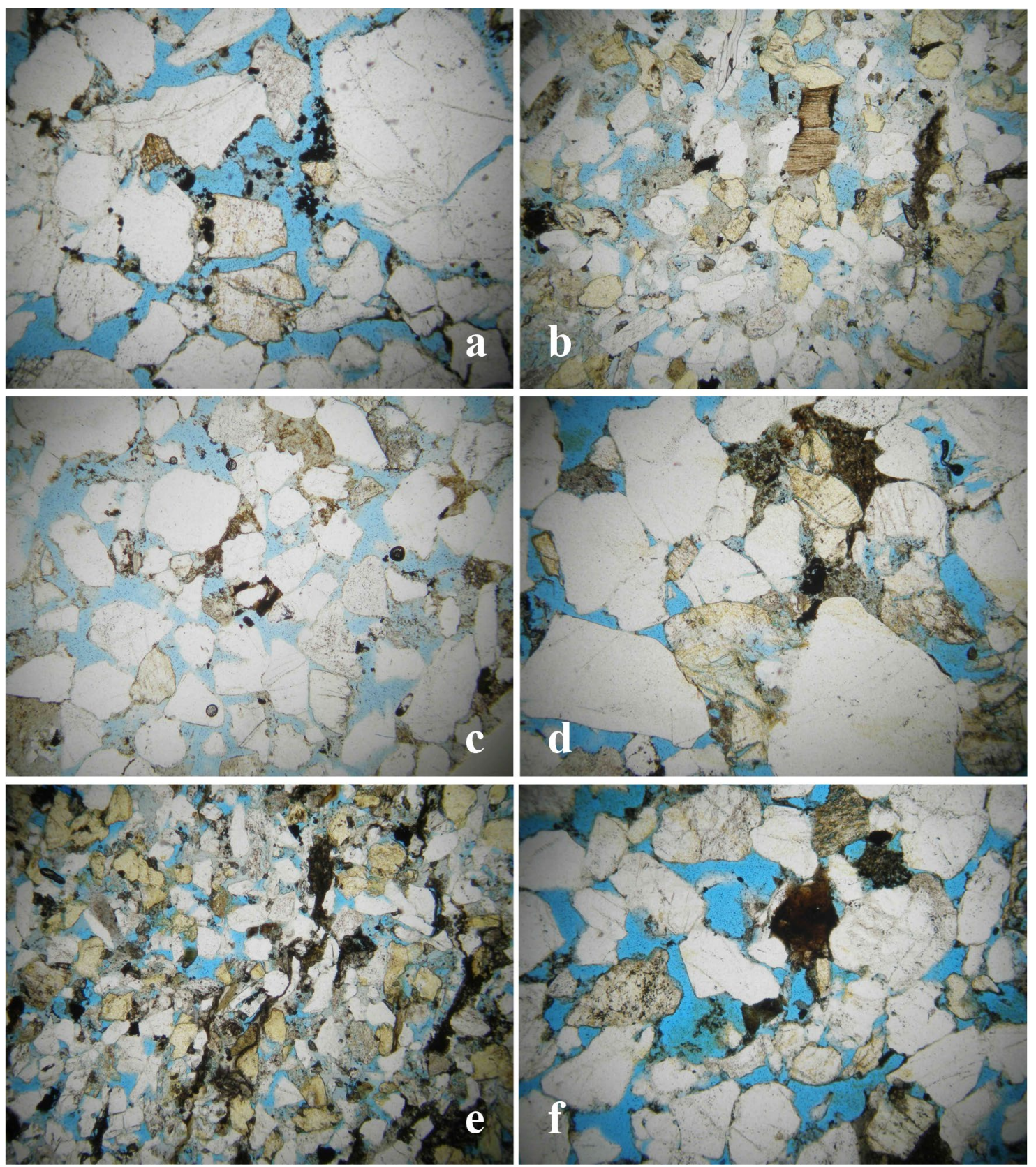

offshore facies successively grade to the NE part of the field (Fig. 25).

\section{Sedimentary depo-facies modeling}

Determining all possible interpreted depo-facies distribution is the key to model the Mangahewa reservoir. Overall, the model covers a length of about $27,000 \mathrm{~m}$ diagonally (following paleoshore trend) and 20,000 $\mathrm{m}$ at its maximum width. Eighteen separate variogram was used in both horizontal and vertical variogram directions for optimum output. Due to the nature of heterogeneity, specific geobody ratios for each facies were applied. Paleoshoreline reconstruction was made as well to better delineate shoreline shifts in exchange of varying sea level responses within the field.

\section{Paleoshoreline reconstruction (PsR)}

Depositional facies model showed the lithological and facies changes during Late Eocene Mangahewa Formation. The model depicted lateral as well as vertical facies variability 
4Fig. 22 Thin-section photomicrograph of the studied wells. The thin sections are representative as it covered from a wide range of depositional settings; marginal marine to shallow marine facies. Plane-polarized light view of conventional core sample. Sample impregnated with blue epoxy resin. View width $2.5 \mathrm{~mm}$. a Clean, coarse-grained and moderately sorted sandstone of Maui-5 (2806 m). Detrital grains are mostly quartz with subordinate feldspar. The grains appear very loosely packed with large and very well-interconnected pores (porosity stained blue). Reservoir quality is excellent. b Fine-grained and moderately well-sorted sandstone of Maui-5 $(2830 \mathrm{~m})$. Detrital grains are mostly quartz with subordinate feldspar (K-feldspar stained patchy yellow-brown). Visible porosity is fairly common (stained blue) with locally large dissolution or hybrid (intergranular/dissolution) pores. However, the pores are variably interconnected, with poorer connectivity in areas with common authigenic clay minerals. Reservoir quality is therefore likely to be moderately good. c Clean, medium-grained and moderately well-sorted sandstone of Maui-5 $(2875 \mathrm{~m})$. Detrital grains are mostly quartz and appear fairly loosely packed. Visible porosity is abundant and comprises large and well-interconnected hybrid pores that are composed of both intergranular and grain dissolution components. Consequently, reservoir quality is excellent. d Clean, coarse-grained and moderately sorted sandstone of Maui-6 (2788 m). Detrital grains are mostly composed of quartz with subordinate feldspar (K-feldspar stained patchy yellow-brown) and minor labile grains. Visible porosity (stained blue) is common and variably well interconnected. However, pore size is very large and hence reservoir quality is likely to be excellent. e Slightly argillaceous, fine-grained and well-sorted sandstone of Maui-6 (2827 m). Detrital grains are mostly quartz with common feldspar (K-feldspar stained patchy yellow-brown) and fairly common labiles. Visible porosity is also fairly common (pores stained blue), yet these pores are variably well interconnected, with fewer, poorly connected pores in the labile-rich laminae. Reservoir quality is moderate. f Clean, coarse-grained and moderately well-sorted sandstone of Maui-6 (2856 m). Detrital grains are mostly quartz and appear fairly loosely packed. Visible porosity is abundant and comprises large and well-interconnected hybrid pores that are composed of both intergranular and grain dissolution components. Consequently, reservoir quality is excellent

within the 3D facies model. This is reflected on the evolving shoreline and coastal depositional fluctuations which in part is related to phases of local sea level rise or fall. For an overall understanding of how the paleoshoreline has shifted, the model is divided into six horizontal slices showing relative positions of the shoreline with respect to the spatial facies distribution. It clearly shows a NE-SW orientation of the coastal facies belt and its constituent subenvironments (Fig. 26). We have interpreted an overall transgression of the facies from older deeper to the younger shallower layers within the model. Tidal channel bodies and estuarine scouring are also clearly evident in the model and appear to be situated in the SW part of the model. Lagoonal bodies and associated facies are observed mainly in the NE section of the model. Offshore bars and reworked sand facies are positioned on the outskirts of the paleoshoreline having NE-SW that gradually move toward north from older deeper to younger shallower layers of the $3 \mathrm{D}$ model. The paleoshoreline reconstruction is therefore an excellent analogy for the literature available on the region based on shoreline shifts due to sea level fluctuations (Stagpoole and Nicol 2008; Kamp et al. 2004).

It is also to be noted that shoreline belt has retained a similar orientation along the layers throughout Late Eocene Mangahewa Formation. Moreover, the stable shift in transgressing shoreline is considered to be due to the overall quiescent tectonic setting associated with passive margin evolution at the head of a large northwest-facing marine embayment (Kamp et al. 2004).

\section{Model validation}

\section{Algorithmic validation}

The selection of SIS depends on several factors. SIS being a simulation which is exclusively based on indicator approach (Gómez-Hernández and Srivastava 1990), it transforms each chosen facies into a new variable and the value of each variable always corresponds to the probability of determining some related facies at a given position. At the present node where the algorithm is implied, it denotes specific facies to a value of 1 , whereas the values for rest of the variables are set to 0 . For better depiction of the subsurface geology of our model, a standard "servo system" (Deutsch 1998; Deutsch and Journel 1992; 1994) is used to improve node matching between the target and the result fraction in case of conflict with the other constraints (i.e., well density, variogram ranges). Principal assistance from this approach is dependent on variability of probability ranges for each node. Based on this approach and independent variogram for each facies, our model is simulated. This process also uses input for geological trend, major/minor direction of the facies and appropriate gridding (in this grid resolution of $50 \times 50 \mathrm{~m}$ is used). Using SIS, we were able to infer required statistical parameters of the facies from limited data, the model was reasonable in settings, the algorithm was robust providing straightforward way for transferring uncertainty in categories through resulting numerical models (Pyrcz and Deutsch 2014; Deutsch 1998).

\section{Comparison of facies to non-facies controlled approach}

Apart from testing different algorithms, facies model is dynamically tested with a unique approach, "facies to nonfacies" controlled modeling. With this approach, in addition to determining algorithm, different iterations have been performed based on a controlled facies trend and without any facies trend. We have noticed that while distributing any specific facies belonging to a sedimentary unit, the model tends to generate better geological picture of the facies that are in closer proximity to the nodes immediately assigned with that

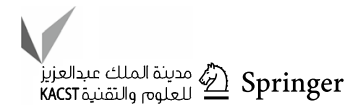




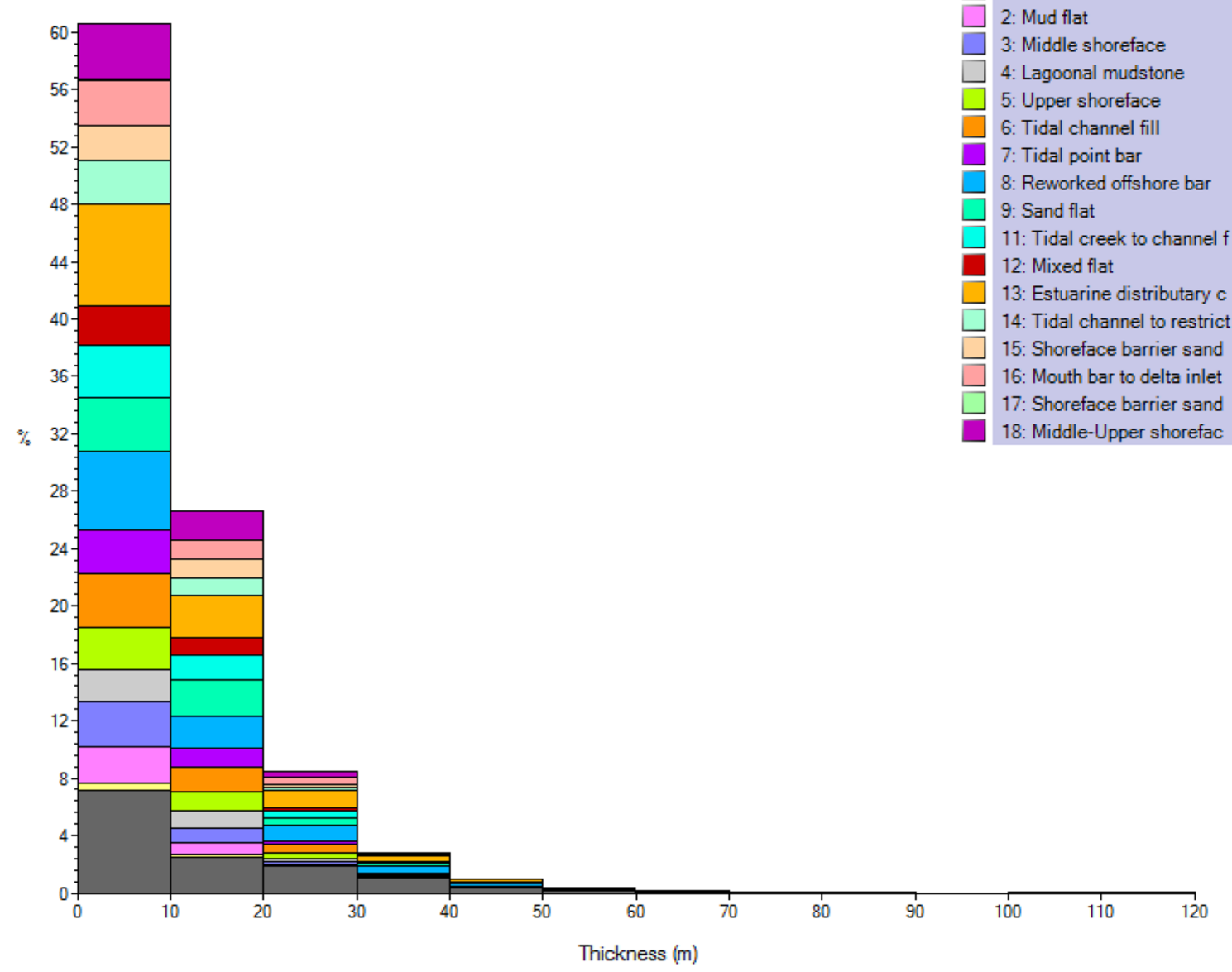

Fig. 23 Thickness distribution of geobodies within the Mangahewa model. The colors are distributed according to the occurrence of the facies

particular facies. So, this is where a controlled approach to horizontal variogram has led us to improve facies architecture. For achieving our desired results, empirical sills and nugget values have been imposed in all the horizontal variograms of the interpreted facies.

Whereas performing the same algorithm (SIS) to a modeled grid devoid of particular facies control, facies tend to be more discrete and are not in accordance with the depositional pattern of the region. Therefore, assigning facies controlled simulation has been a key to verify facies model more rationally and accurately for this study.

\section{Implication of facies modeling to field development}

The facies model has been tested with the available gas-water contact (GWC) of the Mangahewa Formation; hence, the model paves the way for particular facies proportions above the GWC level of the Mangahewa Formation.
Mangahewa Formation has a GWC of -3100 m SSTVD. We have combined the GWC level with the facies model for accurately identifying potential producing facies associations. Figure 27 explains the respective facies above the GWC level of the Mangahewa Formation.

We have concluded that facies those are genetically cleaner, low gamma response, porous and permeable are above the GWC (Fig. 27) of the Mangahewa Formation. Specifically, shoreface sand facies and estuarine facies are potential producing sands from this Mangahewa Formation. Wells that are already drilled also match with the incorporation of the GWC within the facies model. Maui-3, Maui-5 and Maui- 6 that were drilled in the central region of the field show a combination of estuarine, shoreface to barrier sands with occasional tidal sand-dominated channel fills. These facies are relatively cleaner and porous, permeable compared to other facies in the model. Reservoir pressures within this region also show higher pressure regime $(>4000$ 


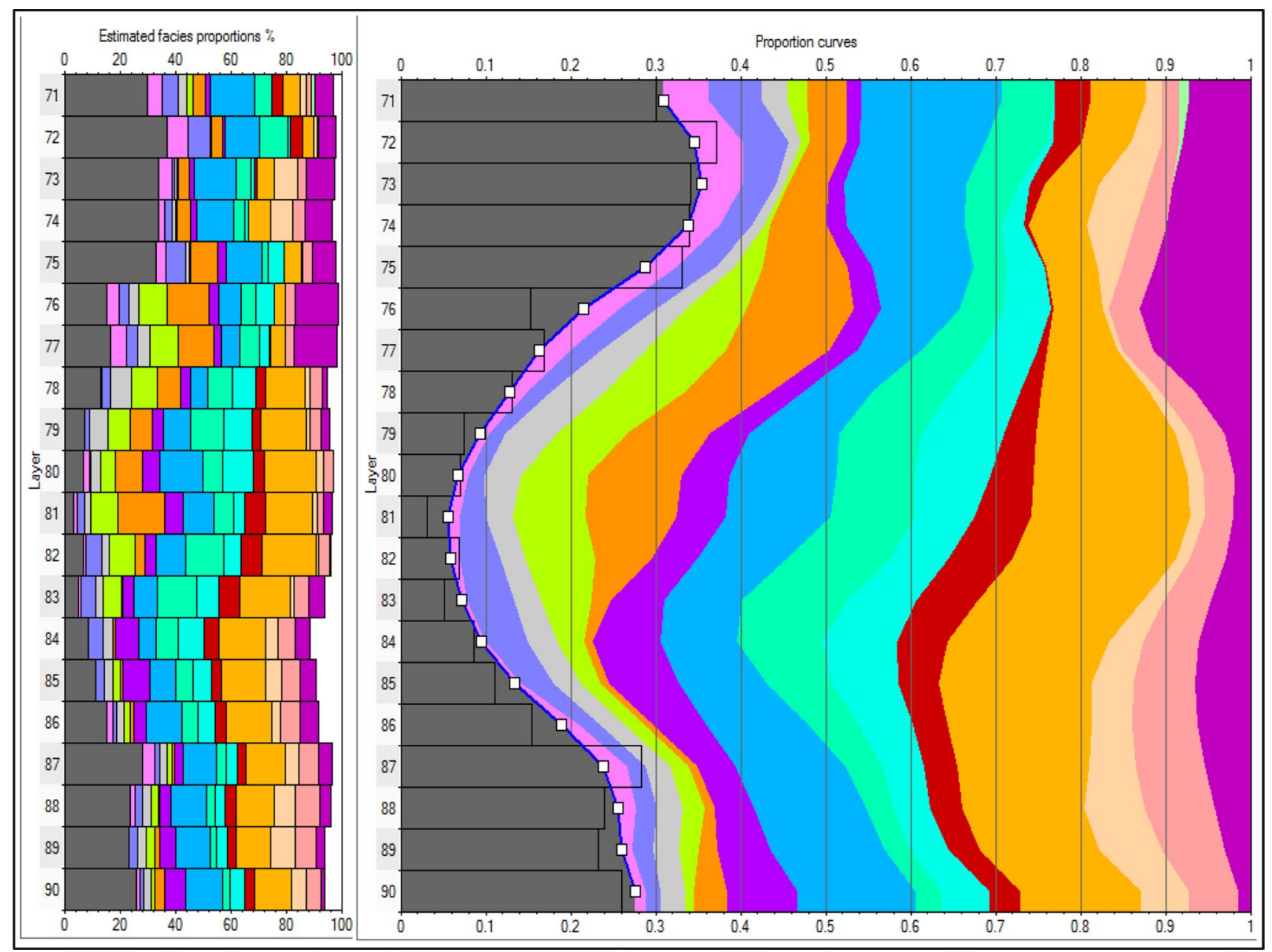

Fig. 24 Facies proportion analyzed in the "data analysis" process. Color legends as of Fig. 23. The proportion curve is dependent on facies variability, uncertainties of occurrence within the grid and three-dimensional geometry (major-minor directions with thickness ratios) used in the geobody model

prompted us to conclude that southern region of the GWC boundary is more prolific compared to the central region in terms of potential production growth and that can be attained by drilling additional wells within the interpreted facies associations.

\section{Conclusion}

The results of the facies simulations have effectively underlined the need for careful synthesis of facies complexity and inter-facies variability while evaluating depositional environments. The following conclusions are drawn based on the depo-facies modeling of the Mangahewa reservoir: information and GWC observations from Fig. 27 have 


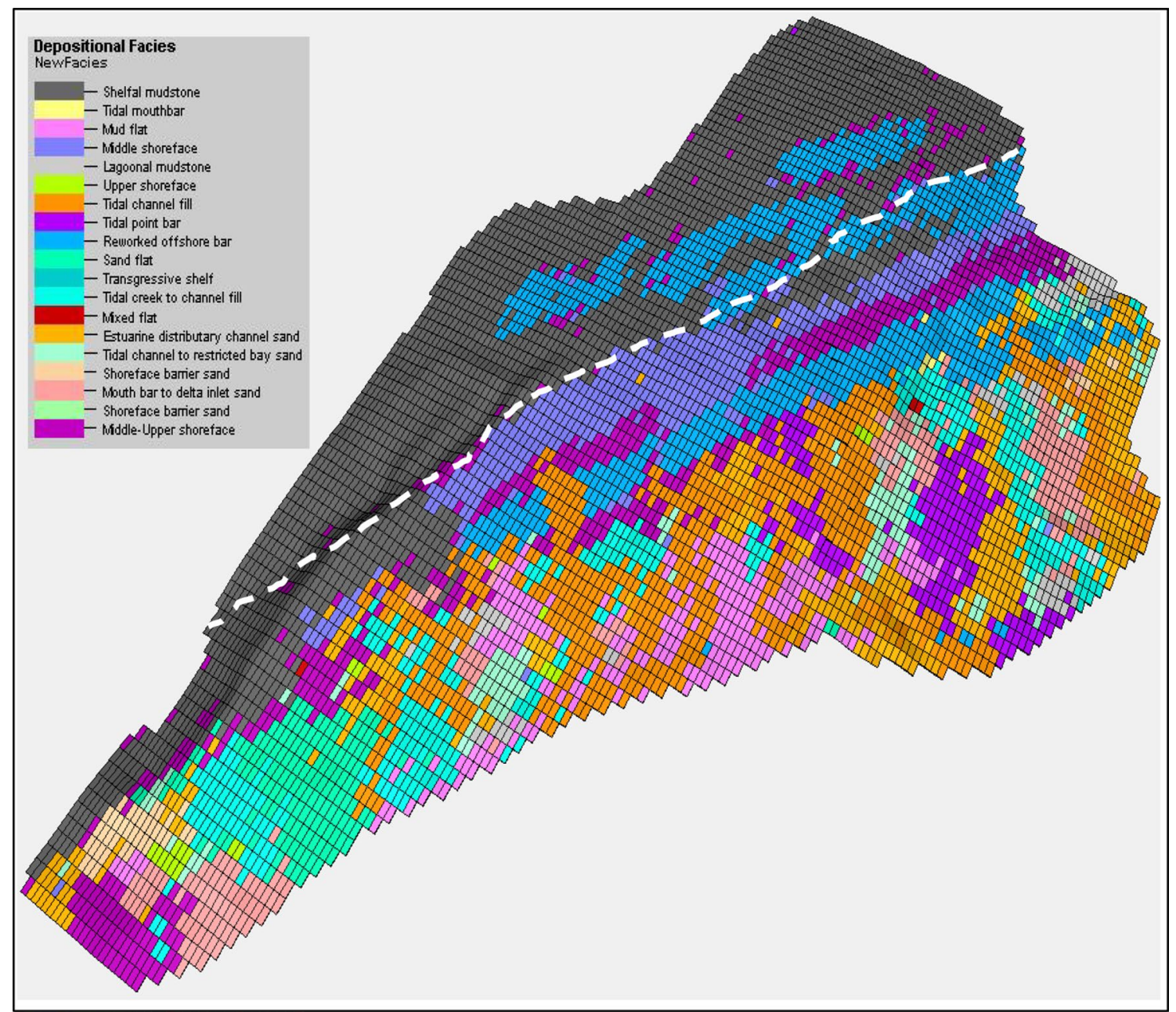

Fig. 25 The figure shows the paleoshoreline in the 3D depositional model of the Mangahewa Formation. The visualized zone (layer 71) in the figure is the youngest (37 Mya) facies within the Mangahewa reservoir

1. Eighteen (18) depo-facies were interpreted that are distributed over three broad paleoenvironmental conditions.

2. Marginal marine was interpreted to be the dominant depositional environment of the formation as a whole having about $64 \%$ of depo-facies, whereas shallow marine environment comprised about $29 \%$ and offshore comprises $7 \%$ of the depo-facies modeled within the Mangahewa Formation, Maui Gas Field.

3. Estuarine channel sands (26\%), shoreface sands (22\%) and tidal channel fills (21\%) were the three major facies occurring with the modeled formation, whereas shelfal mudstone constitutes $7 \%$ of the total facies. Depo-facies modeling also showed that within marginal marine (MM) environment, tidal channel fill, point bar and mouth bar sands occupied $28 \%$ of all the interpreted nodes within the facies model, and tidal flats constituted $10 \%$ of the facies within the Mangahewa reservoir.

4. Geobody model also visualized the transgression of the facies from older deeper to the younger shallower layers within the model. Tidal channel bodies and estuarine scouring were clearly evident in the model and situated in the southwestern region of the model, and lagoonal bodies and associated facies were observed mainly in the northeast section and offshore bars and reworked sand facies were positioned on the outskirts of the paleoshoreline.

5. Paleoshoreline was interpreted to have a broad northeast to southwest trend within the model along with their internal migration over time.

6. Facies model of the studied formation had the effective advantage of quantitative propagation of uncertainty via 


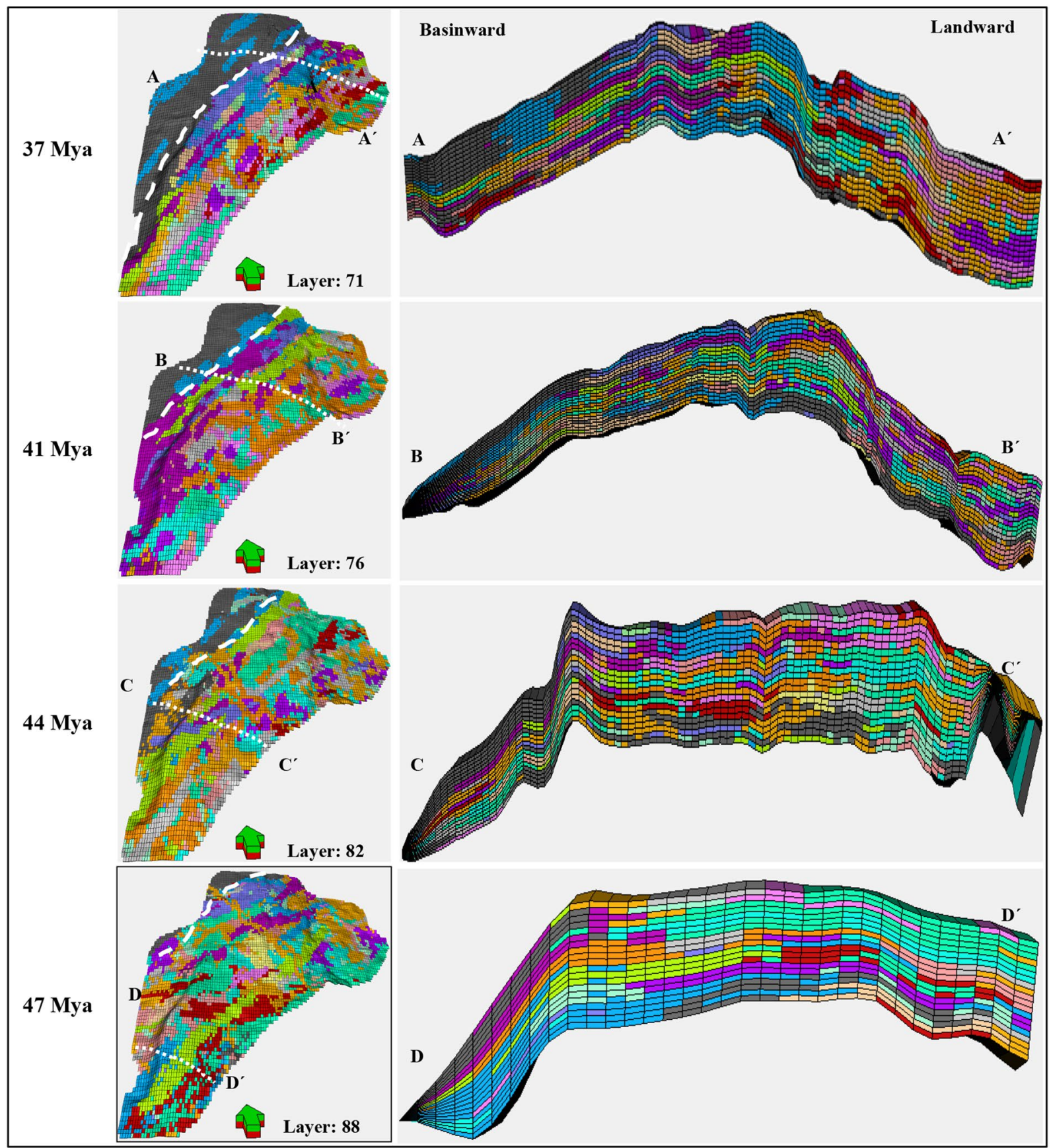

Fig. 26 Paleoshoreline reconstruction from the facies model of the Mangahewa Formation. Color legends as of Fig. 23. The Mid-Late Eocene facies model is older to younger from bottom to top. The

the stochastic representation of the depo-facies identified and spatially distributed across the gas field. Therefore, SIS represented the depositional setup of the formation quite logically.

7. Southern region within the gas-water contact (GWC) boundary was more prolific for potential production depositional facies within the model demonstrates that marine facies progressively move toward the younger layers, therefore suggesting transgression within the facies model

growth compared to the central region and drilling additional wells within the region could be highly productive for future field development within the formation. 


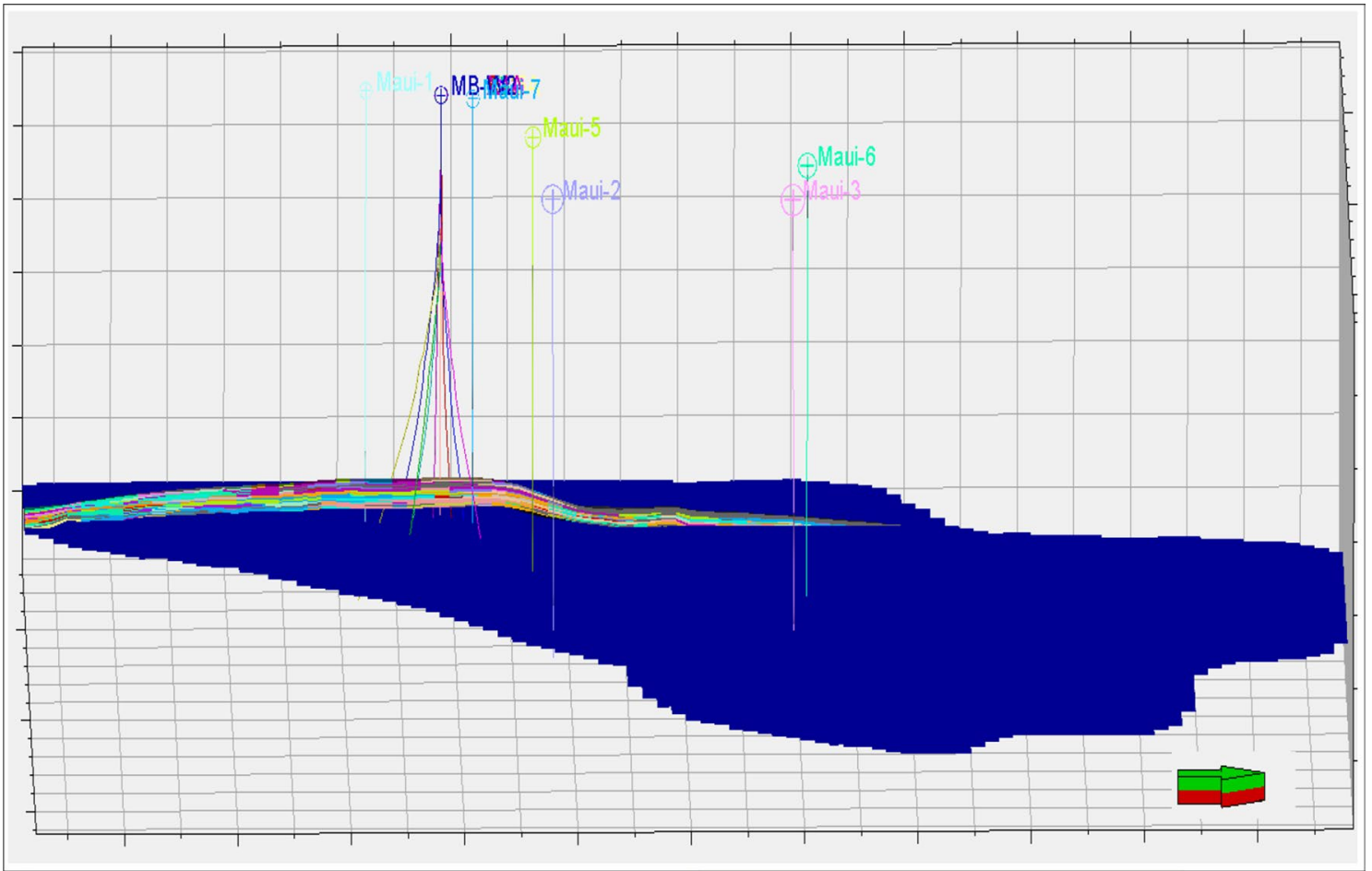

Fig. 27 Facies model incorporating gas-water contact of Mangahewa Formation. Blue layer depicts interpreted gas-water contact for the Mangahewa reservoir. Facies interpreted in the model are potential to produce above contact 


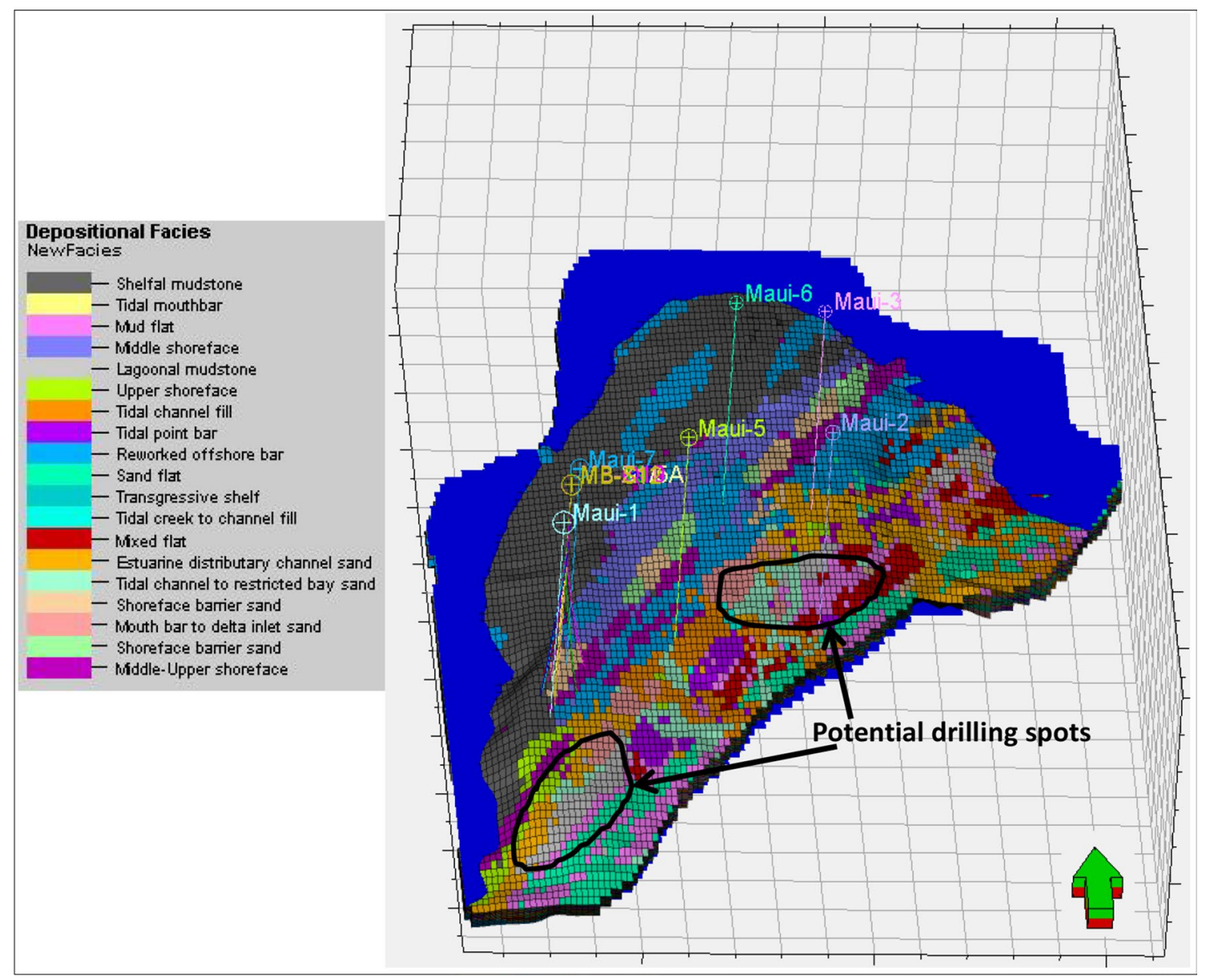

Fig. 28 Facies associations along with potential drilling locations within Mangahewa Formation. Circular black line represents paleoshoreline during the Late Eocene period. The circular spots indicate

Acknowledgements This study has been funded as part of the doctoral research undertaken at the Department of Physical and Geological Sciences, Universiti Brunei Darussalam (UBD), in the form of Graduate Research Scholarship (GRS-2015). The authors would like to thank Ministry of Business, Innovation and Employment (MBIE), New Zealand, for providing dataset containing 3D seismic, well logs and associated reports required for this study. Schlumberger is greatly acknowledged for supporting us with Petrel G\&G software v.2013.1. Two anonymous reviewers are gratefully acknowledged to improve the revised version of the manuscript.

Open Access This article is distributed under the terms of the Creative Commons Attribution 4.0 International License (http://creativeco mmons.org/licenses/by/4.0/), which permits unrestricted use, distribution, and reproduction in any medium, provided you give appropriate credit to the original author(s) and the source, provide a link to the Creative Commons license, and indicate if changes were made.

\section{References}

Abrahim GMS, Nichol SL, Parker RJ, Gregory MR (2008) Facies depositional setting, mineral maturity and sequence stratigraphy potential drilling locations for future field development. Locations are considered based on the abundance of sand-rich geobodies within the Mangahewa reservoir and devoid of previously drilled wells

of a Holocene drowned valley, Tamaki Estuary, New Zealand. Estuar Coast Shelf Sci 79(1):133-142. https://doi.org/10.1016/j. ecss.2008.03.007

Alalade B (2016) Depositional environments of Late Cretaceous Gongila and Fika formations, Chad (Bornu) Basin, Northeast Nigeria. Mar Pet Geol 75:100-116. https://doi.org/10.1016/j. marpetgeo.2016.03.008

Allen JL, Johnson CL (2010) Facies control on sandstone composition (and influence of statistical methods on interpretations) in the John Henry Member, Straight Cliffs Formation, Southern Utah, USA. Sediment Geol 230(1-2):60-76. https://doi. org/10.1016/j.sedgeo.2010.06.023

Barboza SA, Alway R, Akpulat T, Esch WL, Hicks PJ, Gerdes ML (2009) Stochastic evaluation of fluvial to marginal marine sealing facies. Mar Pet Geol 26(4):445-456. https://doi. org/10.1016/j.marpetgeo.2009.01.013

Bloch S, Helmold KP (1995) Approaches to predicting reservoir quality in sandstones 1. Production 1(1):97-115

Boggs S (2011) Principles of sedimentology and stratigraphy. J Chem Inf Model 53:1689-1699. https://doi.org/10.1017/cbo9781107 415324.004

Bryant ID, Marshall MG, Greenstreet CW, Voggenreiter WR, Cohen JM, Stroemmen JF (1994) Integrated geological reservoir modelling of the Maui field, Taranaki Basin, New Zealand. In: 1994 
New Zealand petroleum conference proceedings: the post Maui challenge-investment and development opportunities. Wellington: Energy and Resources Division, pp 256-281

Cacchione DAA, Pratson LFF, Ogston ASS (2002) The shaping of continental slopes by internal tides. Science 296(5568):724-727. https://doi.org/10.1126/science.1069803

Carmona NB, Buatois LA, Ponce JJ, Mangano MG (2009) Ichnology and sedimentology of a tide-influenced delta, Lower Miocene Chenque Formation, Patagonia, Argentina: Trace fossil distribution and response to environmental stresses. Palaeogeogr Palaeoclimatol Palaeocol 273:75-86

Catuneanu O, Abreu V, Bbhattacharya JPP, Blum MDD, Dalrymple RWW, Eriksson PGG, Fielding CR, Fisher WL, Galloway WE, Gibling MR, Giles KA (2009) Towards the standardization of sequence stratigraphy. Earth Sci Rev 92(1):1-33

Cohen J, The R, Mathers R, van den Heuvel E (1996) Integrated subsurface studies aimed towards the development of marginal oil reservoirs in Maui. In: New Zealand petroleum exploration conference proceedings of ministry of economic development, Wellington, New Zealand, pp 133-147

Cross TA, Baker MR, Chapin MA, Clark MS, Gardner MH, Hanson MS, Lessenger MA, Little LD, Mcdonough KJ, Sonnenfeld MD, Valasek DW (1993) Applications of high-resolution sequence stratigraphy to reservoir analysis. Collect Colloq Semin Inst Fr Pet 51:1

Dalrymple RW, Rhodes RW (1995) Estuarine dunes and barforms. In: Perillo GM (ed) Geomorphology and sedimentology of estuaries. Developments in sedimentology. Elsevier, Amsterdam, pp 359-422

Desjardins PR, Buatois LA, Mángano MG (2012) Tidal flats and subtidals and bodies. Dev Sedimentol 64:529-561. https:// doi.org/10.1016/b978-0-444-53813-0.00018-6

Deutsch CV (1998) Cleaning categorical variable (lithofacies) realizations with maximum a posteriori selection. Comput Geosci 24(6):551-562

Deutsch C, Journel A (1992) Geostatistical software library and user's guide. New York. http://www.sepmstrata.org/CMS_Files/book_ review\%20-\%20geostatical-sw.pdf

Deutsch CV, Journel AG (1994) Application of simulated annealing to stochastic reservoir modeling. SPE Adv Technol Ser 2(2):222227. https://doi.org/10.2118/23565-pa

Dorfman MH, Newey JJ, Coates GR (1990) New techniques in lithofacies determination and permeability prediction in carbonates using well logs, geological applications of wireline logs. Geol Soc Lond 48:113-120

Dyer KR, Christie MC, Wright EW (2000) The classification of intertidal mud flats. Cont Shelf Res 20(1):1039-1060

Edmonds DA (2012) Stability of backwater influenced bifurcations: a study of the Mississippi-Atchafalaya bifurcation. Geophys Res Lett 39:L08402

Emery D, Myers KJ (1996) Sequence stratigraphy. Blackwell, oxford, p 297

Gómez-Hernández JJ, Srivastava RM (1990) ISIM3D: an ANSI-C three-dimensional multiple indicator conditional simulation program. Comput Geosci 16(4):395-440

Goovaerts P (2006) Geostatistical modeling of the spaces of local, spatial, and response uncertainty for continuous petrophysical properties. In: Coburn TC, Yarus JM, Chambers RL (eds) Stochastic modeling and geostatistics: principles, methods, and case studies, volume II: AAPG computer applications in geology, vol 5, pp 59-79

Hammer E, Mørk MBE, Næss A (2010) Facies controls on the distribution of diagenesis and compaction in fluvial-deltaic deposits. Mar Pet Geol 27(8):1737-1751
Haque AKME, Islam MdA, Shalaby MR (2016) Structural modeling of the Maui gas field, Taranaki Basin, New Zealand. J Pet Explor Dev 43(6):965-975

Harding A, Strebelle S, Levy M, Thorne J, Xie D, Leigh S, Preece R, Scamman R (2004) Reservoir facies modelling: new advances in mps. In: Geostatistics Banff, pp 559-568

Harishidayat D, Johansen SE (2015) 3D seismic interpretation of the depositional morphology of the Middle to Late Triassic fluvial system in Eastern Hammerfest Basin, Barents Sea. Mar Pet Geol 68:470-479

Helland-Hansen WI (2010) Facies and stacking patterns of shelf-deltas within the Palaeogene Battfjellet Formation, Nordenskiöld Land, Svalbard: implications for subsurface reservoir prediction. Sedimentology 57(1):190-208

Higgs KE, King PR, Raine JI, Sykes R, Browne GH, Crouch EM, Baur JR (2012) Sequence stratigraphy and controls on reservoir sandstone distribution in an Eocene marginal marine-coastal plain fairway, Taranaki Basin, New Zealand. Mar Pet Geol 32(1):110-137

Howell JA, Skorstad A, Macdonald A, Fordham A, Flint S, Fjellvoll B, Manzocchi T (2008) Sedimentological parameterization of shallow-marine reservoirs. Pet Geosci 14(1):17-34

Jadoon QK, Roberts EM, Henderson B, Blenkinsop TG, Wüst RA, Mtelela C (2017) Lithological and facies analysis of the Roseneath and Murteree shales, Cooper Basin, Australia. J Nat Gas Sci Eng 37:138-168

Kamp PJ, Vonk A, Bland J, Kyle J, Hansen RJ, Hendy AJ, Mcintyre AP, Ngatai M, Cartwright SJ, Hayton S, Nelson CS (2004) Neogene stratigraphic architecture and tectonic evolution of Wanganui, King Country, and eastern Taranaki Basins, New Zealand. N Z J Geol Geophys 47(4):625-644

Karlin S, Taylor H (1998) An introduction to stochastic modeling, 3d edn, $\mathrm{p} 631$

King PR (1990) Polyphase evolution of the Taranaki Basin, New Zealand: changes in sedimentary and structural style. In: New Zealand oil exploration conference proceedings, pp 134-150

King PR, Thrasher GP (1992) Post-Eocene development of the Taranaki Basin, New Zealand, convergent overprint of a passive margin. Am Assoc Pet Geol Mem 53:93-118

King PR, Thrasher GP (1996) Cretaceous-Cenozoic geology and petroleum systems of the Taranaki Basin, New Zealand. In: Institute of geological and nuclear sciences, vol 13, no 2, Lower Hutt

King PR, Browne GH, Slatt RM (1995) High resolution sequence stratigraphy of Miocene deepwater clastic outcrops, Taranaki coast, New Zealand. In: American Association of petroleum geologists international conference and exhibition abstracts, vol 37

Kupfersberger H, Deutsch CV (1999) Methodology for integrating analog geologic data in 3-D variogram modeling. AAPG Bull 83(8): 1262-1278

Kupfersberger H, Deutsch CV, Journel AG (1998) Deriving constraints on small-scale variograms due to variograms of largescale data. Math Geol 30(7):837-852

Laird MG (1993) Cretaceous continental rifts: New Zealand region. South Pacific Sedimentary Basins. Sediment Basins World 2:37-49

Li W, Bhattacharya JP, Zhu Y, Garza D, Blankenship E (2011) Evaluating delta asymmetry using three-dimensional facies architecture and ichnological analysis, Ferron 'Notom Delta', Capital Reef, Utah, USA. Sedimentology 58(2):478-507

Li S, Ma YZ, Yu X, Jiang P, Li M (2014) Change of deltaic depositional environment and its impacts on reservoir properties-a braided delta in South China Sea. Mar Pet Geol 58:760-775

Mayall M, Jones E, Casey M (2006) Turbidite channel reservoirs-key elements in facies prediction and effective development. Mar Pet Geol 23(8):821-841 
Miall A (2016) Facies model (book series), pp 176-181

Myers DE (2006) Reflections on geostatistics and stochastic modeling. In: Coburn TC, Yarus JM, Chambers RL (eds) Stochastic modeling and geostatistics: principles, methods, and case studies, volume II. AAPG computer applications in geology, vol 5, pp 11-22

Nicoletta L, Alberto CTS, Sergio F (2012) Effect of tides on mouth bar morphology and hydrodynamics. Restor Sedimentol Nat Geosci 5(11):758-759

Palmer J, Bulte G (1991) Taranaki Basin, New Zealand. AAPG Mem 52:261-282

Pashin JC, Gastaldo RA, Flores RM (2004) Coal buildup in tide-influenced coastal plains in the Eocene Kapuni group, Taranaki Basin, New Zealand

Plint AG, Eyles N, Eyles CH, Walker RG (1992) Control of sea level change. Facies models; response to sea level change. Geological Association of Canada, St. Johns, pp 15-25

Pritchard D, Hogg AJ, Roberts W (2002) Morphological modelling of intertidal mudflats: the role of cross-shore tidal currents. Contin Shelf Res 22(11):1887-1895

Pyrcz MJ, Deutsch CV (2014) Geostatistical reservoir modeling. Oxford University Press, Oxford, pp 127-131

Pyrcz MJ, Mchargue T, Clark J, Sullivan M, Strebelle S (2012) Event-based geostatistical modeling: description and applications. In: Geostatistics, pp 27-38

Rahmani RA (1988) Estuarine tidal channel and nearshore sedimentation of a Late Cretaceous epicontinental sea, Drumheller, Alberta, Canada. In: Tide-influenced sedimentary environments, pp 433-471

Reading HG, Collinson JD (1996) Sedimentary environments: processes, facies and stratigraphy, 3rd edn. Blackwell Science, Oxford, pp 154-231

Reineck HE, Singh IB (1980) Depositional sedimentary environments, with reference to terrigenous clastics, 2nd edn. Springer, Berlin

Rodríguez-Tovar FJ, Dorador J, Mayoral E, Santos A (2017) Outcrop and core integrative ichnofabric analysis of Miocene sediments from Lepe, Huelva (SW Spain): improving depositional and paleoenvironmental interpretations. Sediment Geol 349:62-78

Seybold OM, Greenstreet CW, Hawton DA (1996) Reservoir management of the giant Maui Gas/condensate field. In: New Zealand petroleum exploration conference proceedings. Ministry of Economic Development, Wellington, New Zealand, pp 125-132
Shanmugam G, Poffenberger M, Alava JT (2000) Tide-dominated estuarine facies in the Hollin and Napo. AAPG Bull 84(5):652-682

Stagpoole V, Nicol A (2008) Regional structure and kinematic history of a large subduction back thrust: Taranaki Fault, New Zealand. J Geophys Res 113:B01403

Strebelle S, Zhang T (2004) Non-stationary multiple-point geostatistical models. In: Geostatistics Banff, pp 235-244

Strebelle S, Pyrcz M, Ainley C, Thorne J (2016) Reservoir property trend modeling guidance using data-driven uncertainty range, Chevron USA, Inc., United States Patent US 20,160,048,933

Turner GM, Bryant ID (1995) Application of a palaeomagnetic reversal stratigraphy to constrain well correlation and sequence stratigraphic interpretation of the Eocene C1 Sands, Maui Field, New Zealand. Geol Soc Lond Spec Publ 98(1):205-221

Voggenreiter WR (1993) Structure and evolution of the Kapuni Anticline, Taranaki Basin, New Zealand: evidence from the Kapuni 3D seismic survey. N Z J Geol Geophys 36(1):77-94

Walker M, Grant S, Connolly P, Smith L (2016) Stochastic inversion for facies: a case study on the Schiehallion field. Interpretation 4(3):9-20

Wang X, Collett TS, Lee MW, Yang S, Guo Y, Wu S (2014) Geological controls on the occurrence of gas hydrate from core, downhole $\log$, and seismic data in the Shenhu area, South China Sea. Mar Geol 357:272-292

Xu W, Journel AG (1993) GTSIM: gaussian truncated simulations of reservoir units in a W. Texas carbonate field. SPE 27412:3-6

Yoshida S, Johnson HD, Pye K, Dixon RJ (2004) Transgressive changes from tidal estuarine to marine embayment depositional systems: the lower cretaceous Woburn sands of southern England and comparison with Holocene analogs. AAPG Bull 88(10):1433-1460

Zhong G, Liang J, Guo Y, Kuang Z, Su P, Lin L (2017) Integrated core-log facies analysis and depositional model of the gas hydratebearing sediments in the northeastern continental slope, South China Sea. Mar Pet Geol 86:1159-1172

Publisher's Note Springer Nature remains neutral with regard to jurisdictional claims in published maps and institutional affiliations.

1 